Review article

Nutritional Research Section

\title{
Coffee and its Biologically Active Components: Is There a Connection to Breast, Endometrial, and Ovarian Cancer? - a Review
}

\author{
Anna M. Witkowska*, Iwona Mirończuk-Chodakowska, Katarzyna M. Terlikowska, \\ Kamila Kulesza, Matgorzata E. Zujko
}

\author{
Department of Food Biotechnology, Faculty of Health Sciences, Medical University of Bialystok, \\ Szpitalna 37, 15-295 Bialystok, Poland
}

Key words: coffee, caffeine, breast cancer, ovarian cancer, endometrial cancer

Coffee is an important dietary source of biologically active components, not to mention caffeine, phenolic acids, and diterpenes. It has been suggested that selected coffee secondary metabolites may beneficially modulate several mechanisms of anti-cancer protection. This literature review was intended to present current knowledge related to coffee and its components and hormone-dependent female cancers, such as breast, endometrial and ovarian cancer, and to identify gaps in research that may be exploited in the future. The search for studies was conducted through electronic databases. Publications on coffee composition, coffee preparation and brewing methods, in vitro and in vivo experiments with the use of substances naturally present in coffee, observational studies, and meta-analyses were collected. In population studies, the greatest attention has been paid to the anticancer effect of caffeinated coffee and/or caffeine. In general, most studies and meta-analyses indicated that there was no clear correlation between coffee and breast cancer or ovarian cancer. Some subgroups of women may benefit from coffee consumption. This is the case for post-menopausal women with regard to the risk of breast cancer and obese women with regard to the risk of endometrial cancer. This paper identifies a number of issues for future research, related to a better understanding of the anti-cancer mechanisms of coffee compounds and further research that would focus on specific target groups, taking into account both the different methods of coffee preparation and lifestyle factors that may influence the results.

\section{INTRODUCTION}

Coffee is one of the most popular beverages in the world because of its taste, aroma and stimulating properties, but the perception of coffee as a potentially health-promoting component of the diet is not very high in the global population [Samoggia \& Riedel, 2019]. Except some cases, like pregnancy or sensitivity to some coffee compounds, coffee can offer many beneficial health effects [Grosso et al., 2016, 2017a; Poole et al., 2017; Wierzejska, 2016]. Interestingly, a recent exploratory study has shown that coffee consumption may modulate the expression of 297 genes in healthy women in different ways [Barnung et al., 2018], thus affecting metabolic and inflammatory pathways. Several lines of evidence have linked coffee consumption to a reduced risk of cardiovascular diseases [Poole et al., 2017; Rodríguez-Artalejo \& López-García, 2018], cancer [Gapstur et al., 2017; Grosso et al., 2017a], neurodegenerative diseases [Liu et al., 2016; Qi \& Li, 2014], and diabetes [Ding et al., 2014], as well as to a lower cancer mortality and all-cause mortality [Grosso et al., 2017b; Gunter et al., 2017; Poole et al., 2017]. On a molecular basis, regular coffee consumption preserves the integ-

\footnotetext{
* Corresponding Author: Tel.: 85 6865090; Fax: 856865089

E-mail: anna.witkowska@umb.edu.pl

rity of DNA by decreasing spontaneous DNA strand breaks [Bakuradze et al., 2015].

Cancers in women are a serious global health problem and a leading cause of death. They are responsible for a quarter of the deaths of women in Europe [European Commission, 2019] and a fifth in the USA [Centers for Disease Control and Prevention, 2019]. In sex hormone-dependent cancers, abnormal estrogen and progesterone levels are among the risk factors [Brown \& Hankinson, 2015; Diep et al., 2015]. With 24.2\% incidence, breast cancer cases are the most common in women [Bray et al., 2018]. In the global incidence of female cancers, endometrial (4.4\%) and ovarian cancers (3.4\%) rank sixth and eighth, respectively [Bray et al., 2018].

Coffee is a source of biologically active compounds, many of which have anti-cancer properties. However, observational studies with humans, which focus mainly on coffee consumption (caffeinated or decaffeinated) and caffeine intake, show rather conflicting results for breast, uterine, and ovarian cancer. This literature review aims to present current research related to coffee and its components and hormone-dependent female cancers, such as breast, endometrial, and ovarian cancer, and to identify gaps in research that may be exploited in the future. 


\section{SEARCH STRATEGY}

From the point of view of current knowledge, the search for studies from the last decade, i.e. from 2010 to 2019, was conducted through the electronic databases: Medline and Web of Science. Publications on coffee composition, coffee preparation and brewing methods, in vitro and in vivo experiments with the use of substances naturally present in coffee, observational studies, and meta-analyses were collected. In some cases, with the exception of case-control and epidemiological studies, studies that were important for this review, but outside the search period, were described as well. The search terms were multiple with "coffee" as a broad search term, and in combination with "breast cancer", "ovarian cancer", and "endometrial cancer" as the most critical for this review. The articles published in English that were relevant for this review were selected.

\section{BIOACTIVE COMPOUNDS OF COFFEE}

Roasted coffee beans are composed of several substances derived from different chemical groups, not to mention caffeine, phenolic acids, and diterpenes. Their contents in a coffee brew depend, to a large extent, on the type of coffee bean (Coffea arabica vs. Coffea canephora var. robusta), roasting parameters, as well as the methods of brewing. A coffee brew contains substances that are only specific to coffee, such as diterpenes - cafestol and kahweol [Gross et al., 1997; Zhang et al., 2012]. Others, such as caffeine, can be found in tea, cola-type beverages, and chocolate.

\section{Caffeine}

Caffeine is a heat-stable methylxanthine alkaloid (Figure 1) present mainly in coffee, tea, guarana, cola-type soft drinks, cacao, and chocolate. It is very soluble in boiling water. Depending on the type of coffee preparation (ground, instant) or brewing methods (boiling, filtering, French pressing,), coffee may contain 19-803 mg caffeine per serving (Table 1). Decaffeinated coffee, in turn, presents considerably reduced caffeine content $<9 \mathrm{mg} /$ serving.

Several beneficial or adverse biological effects are attributable to caffeine. As an adenosine receptor antagonist, it is a central nervous system stimulant and anti-inflammatory agent [Madeira et al., 2017]. In vitro studies have demonstrated cell cycle modulating and apoptotic properties of caffeine, mediated through various mechanisms, that can lead to tumor suppression [He et al., 2003; Ito et al., 2003; Saiki et al., 2011]. Caffeine also exhibits antiproliferative activity in ovarian cancer cells, even several times higher than that of chlorogenic acid and caffeic acid [Tai et al., 2010]. Besides, it may possibly alter circulating levels of luteal estrogens and sex hormone-binding globulin (SHBG), and thereby affect the development of cancers [Kotsopoulos et al., 2009]. Variants in cytochrome P-450 (CYP) genes involved in caffeine metabolism may increase or decrease the risk of ovarian cancer development [Kotsopoulos et al., 2009]. It has been<smiles>Cn1c(=O)c2c(ncn2C)n(C)c1=O</smiles>

Caffeine<smiles>O=C(O)/C=C/c1ccc(O)c(O)c1</smiles>

Caffeic acid<smiles>O=C(/C=C/c1ccc(O)c(O)c1)OC1C[C@@](O)(C(=O)O)C[C@H](O)[C@H]1O</smiles>

Chlorogenic acid<smiles>C[C@@H]1[C@@H](CO)[C@@H](O)C[C@]12CC[C@@H]1c3ccoc3CC[C@]1(C)C2</smiles>

Cafestol

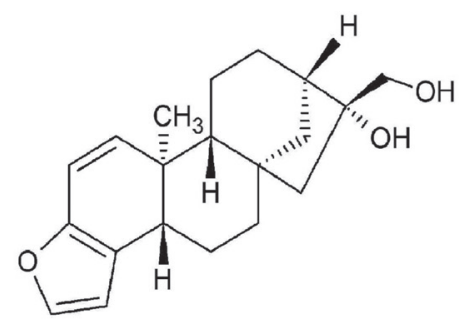

Kahweol

Ferulic acid<smiles>C[n+]1cccc(C(=O)[O-])c1</smiles>

Trigonelline<smiles>C=CC(N)=O</smiles>

Acrylamide

FIGURE 1. Chemical structure of major coffee compounds. 
TABLE 1. Caffeine contents in varied coffee infusions*.

\begin{tabular}{lcc}
\hline Coffee infusion type & $\begin{array}{c}\text { Caffeine content } \\
(\mathrm{mg} / \mathrm{L})\end{array}$ & $\begin{array}{c}\text { Caffeine content } \\
(\mathrm{mg} \text { per serving**) }\end{array}$ \\
\hline Boiled/ Turkish & $850-2330$ & $201-552$ \\
Decaffeinated & $1-37$ & $0.24-8.77$ \\
Espresso & $722-5334$ & $19-144$ \\
Filtered & $397-2008$ & $81-416$ \\
French press & $520-1564$ & $123-371$ \\
Instant & $390-2690$ & $92-638$ \\
Mocha & $924-2268$ & $327-803$ \\
\hline
\end{tabular}

*adopted from: [dePaula \& Farah, 2019]; **serving size for coffee: boiled/ Turkish, French press, instant, decaffeinated, $237 \mathrm{~mL}$; espresso $27 \mathrm{~mL}$; filtered $207 \mathrm{~mL}$; mocha $354 \mathrm{~mL}$.

suggested that caffeine from coffee may protect against endometrial cancer [Hashibe et al., 2015].

\section{Coffee diterpenes}

Diterpenes are organic compounds that consist of four isoprene units. In coffee, their main representatives include cafestol and kahweol (Figure 1), which are specific to the lipid fraction of coffee. In filtered coffees, this lipid fraction is absorbed by the cellulose paper filter [Gross et al., 1997]. Therefore, the contents of cafestol and kahweol in filtered coffee are negligible. Higher levels of diterpenes have been found in Coffea arabica than in C. robusta [Mensink et al., 1995]. The content of coffee diterpenes varies between 0.02-9 mg cafestol per serving and 0.02-7.2 mg kahweol per serving, depending on the coffee preparation procedure (Table 2).

Coffee diterpenes cause controversy because they may increase the levels of serum total cholesterol and LDL cholesterol fraction [Mensink et al., 1995]. Cafestol and kahweol demonstrate several biologically beneficial properties and are known as inducers of glutathione $S$-transferase, the enzyme which catalyzes detoxication reaction via conjugation of xenobiotics with the sulfhydryl group of glutathi- one [Huber \& Parzefall, 2005]. Consequently, conjugates are eliminated. Several lines of evidence connect coffee-specific diterpenes with anticancer properties. In male F344 rats, kahweol and cafestol (1:1) or only cafestol caused an increase in the level of hepatic O(6)-methylguanine-DNA methyltransferase (MGMT), an enzyme which is involved in the reversal of precarcinogenic damage of $\mathrm{O}(6)$-alkylguanine, a DNA adduct formed by alkylating agents in a dose-dependent manner [Huber et al., 2003]. Anticancerogenic activity of coffee diterpenes was observed in several cancer cell lines. Most of the papers on female cancers in conjunction with coffee diterpenes have so far been limited to mammary tumors. Antitumor activity of kahweol was tested in a few cancer cell lines. It has been shown to be manifested in both inhibited tumor cell growth and clonogenicity, and a decreased survival of cancer cells [Cárdenas et al., 2014]. These effects were mostly pronounced in estrogen-negative human breast cancer cells MDA-MB231, and were accompanied by the activation of caspases 3/7 and 9, and the release of cytochrome c. Kahweol increased the production of reactive oxygen species (ROS) and their cytotoxicity against breast cancer cells, but it did not affect the healthy cells [Cárdenas et al., 2014]. Other anticancer properties of kahweol are associated with its antiangiogenic and anti-inflammatory characteristics [Cárdenas et al., 2011].

Cafestol has recently been hypothesized as a preventive compound in the pathology of diabetes [Mellbye et al., 2015]. In recent years, the link between diabetes and cancer has become of particular interest. With regard to the results of the research published in the last few years, diabetes can be thought of as a risk factor for certain types of cancer, including endometrial cancer. In an in vitro study, cafestol acutely stimulated insulin secretion from $\beta$-cells and improved insulin sensitivity in skeletal muscle cells.

\section{Phytoestrogens}

Phytoestrogens (plant estrogens) are compounds with a structural similarity to estradiol (E2), the primary female sex hormone. By binding to estrogen receptors (ERs), phytoestrogens can induce different biological activities asso-

TABLE 2. Diterpene contents in various coffee infusions*.

\begin{tabular}{l|c|c|c|c}
\hline \multirow{2}{*}{ Coffee infusion type } & \multicolumn{2}{|c|}{ Cafestol } & \multicolumn{2}{c}{ Kahweol } \\
\cline { 2 - 5 } & (mg/L) & (mg per serving**) & (mg/L) & mg per serving** \\
\hline Boiled & $26-49$ & $4-8$ & $48.0+2.5$ & 1.2 \\
Espresso & $22-30$ & 1.0 & $16.3-17.1$ & 0.02 \\
Filtered & $0.12+0.02$ & 0.02 & $0.14+0.03$ & - \\
French press & $29-53$ & $5-9$ & - & $0.1-0.3$ \\
Instant & $0.7-1.9$ & $0.1-0.3$ & $3.7-1.9$ & 2.3 \\
Mocha & $19-33$ & $1-2$ & $38.5+0.9$ & $59.9+4.1$ \\
Turkish & $23-41$ & $1.4-2.5$ & 5.4 \\
\hline
\end{tabular}

*adopted from: [Zhang et al., 2012; Buchmann et al., 2011; Gross et al., 1997];**serving size for coffee: boiled, 150-160 mL; French press 160 mL; filtered, instant $150 \mathrm{~mL}$; espresso, mocha, Turkish $60 \mathrm{~mL}$. 
ciated with estrogenic or anti-estrogenic activity [Rietjens et al., 2017].

Coffee contains rather small amounts of phytoestrogens, which belong to different classes of polyphenols, such as lignans and isoflavones. Ground coffee is a source of lignan secoisolariciresinol in average amounts of $5.61 \mathrm{mg} / \mathrm{kg}$ but does not contain matairesinol [Mazur et al., 1998]. In a recent study, lignans found in espresso coffee prepared from coffee samples from 5 different geographical regions comprised secoisolariciresinol, from 27.9 to $52.0 \mu \mathrm{g} / \mathrm{L}$, and lariciresinol, from 5.3 to $27.8 \mu \mathrm{g} / \mathrm{L}$ [Angeloni et al., 2018]. Again, matairesinol was not detected. Considering the consumption of lignans in the range of 1000-2000 $\mu \mathrm{g} / \mathrm{d}$ in European countries [Tetens et al., 2013; Witkowska et al., 2018], the usual daily coffee intake of 2-3 coffee cups may provide a mere $1.3-2.4 \%$ of total lignans. In the intestines, lignans are metabolized by anaerobic bacteria to enterolignans such as enterolactone and enterodiol, which demonstrate estrogenic activity [Zhu et al., 2017]. Enterodiol was also found in coffee brews in amounts ranging from 97 to $135 \mu \mathrm{g} / \mathrm{L}$ [Sapozhnikova, 2014].

Isoflavones found in coffee are mainly daidzein, genistein, and formononetin. In ground coffee, they account for $3.2-5.2 \mathrm{mg} / \mathrm{kg}, 0.9-1.4 \mathrm{mg} / \mathrm{kg}$, and $3-6 \mu \mathrm{g} / \mathrm{kg}$, respectively [Sapozhnikova, 2014]. Overall, isoflavone consumption in Europe has been described as low, and originated mainly from soybean products [Zamora-Ros et al., 2012].

\section{Chlorogenic, caffeic, and ferulic acids}

Structurally, chlorogenic, caffeic, and ferulic acids are phenolic compounds that are classified as hydroxycinnamic acids (Figure 1). Ferulic acid (4-hydroxy-3-methoxy cinnamic acid) is synthesized in plants from caffeic acid (3,4-dihydroxycinnamic acid). Chlorogenic acid is an ester of caffeic and quinic acids (3-caffeoylquinic acid). In nature, there is a whole range of different derivatives of hydroxycinnamic acids, which are also typical of green coffee. They are intermediates in lignin biosynthesis. Hydroxycinnamic acids are ubiquitous in plant foods, but their significant amounts were also found in coffee. Therefore, coffee can be the main source of hydroxycinnamic acids in countries with high coffee intake [Witkowska et al., 2015]. Caffeoylquinic acids, which are the main hydroxycinnamic acids in coffee, can vary in coffee infusions up to a wide range of 6-188 mg/cup [Jeon et al., 2019; Ludwig et al., 2014]. They have been ascribed various activities related to carcinogenesis. On the one hand, hydroxycinnamate demonstrates antioxidant, anti-inflammatory, antidiabetic, and antimicrobial potential [Teixeira et al., 2013; Vinholes et al., 2015]. But on the other hand, chlorogenic acid, caffeic acid, and caffeic acid phenethyl ester (CAPE) are in vitro inhibitors of catechol-O-methyltransferase (COMT)-mediated $O$-methylation of catechol estrogens to their less estrogenic derivatives [Zhu et al., 2009]. This inhibition of COMT may lead to the reduced formation of antiproliferative 2-methoxyestradiol and increased accumulation of reactive catechol estrogen intermediates, which may affect cancer development. Interestingly, caffeic acid has been recently suggested as an enhancer of ovarian cancer cells' resistance to treatment [Sirota et al., 2015].

\section{Trigonelline}

Trigonelline ( $N$-methylnicotinic acid), a product of mammalian metabolism of niacin (vitamin $\mathrm{B}_{3}$ ), is an alkaloid that also occurs in various plants. Its chemical structure is presented in Figure 1. After caffeine, it is the second most abundant alkaloid in coffee [Acidri et al., 2020], with average concentration approximating $300 \mathrm{mg} / \mathrm{L}$ [Lang et al., 2008]. During the roasting process, much of the trigonelline is degraded to nicotinic acid [Lang et al., 2008].

Trigonelline may have estrogenic properties. In estrogen-dependent human breast cancer cells MCF-7, it has been reported to enhance cell proliferation, induce activation of estrogen response element (ERE), and activate ERs [Allred et al., 2009].

Many compounds found in plants exhibit antioxidant properties. However, trigonelline was identified as a potent suppressor of the Nrf2/ARE pathway [Boettler et al., 2011], which regulates the expression of genes involved in cellular antioxidant and anti-inflammatory protection. In turn, trigonelline degradation product, the $N$-methylpyridinium ion (NMP) - which is formed during the roasting process, has strong, long-lasting effects that enhance Nrf2/ARE-dependent gene expression [Boettler et al., 2011].

\section{Acrylamide}

The most relevant dietary sources of acrylamide are solid coffee constituents, coffee, and fried potato products [EFSA Panel on Contaminants in the Food Chain (CONTAM), 2015; Freisling et al., 2013]. Acrylamide molecules are formed in coffee beans during the process of roasting. The acrylamide content of coffee can vary greatly. In European countries, its average content in ground coffee was estimated at $225-231 \mu \mathrm{g} / \mathrm{kg}$ (depending on the year of sampling), while the maximum value of up to $2223 \mu \mathrm{g} / \mathrm{kg}$ [EFSA, 2011]. For instant coffee, these results were higher with an average value of $357-595 \mu \mathrm{g} / \mathrm{kg}$ and a maximum value of $1470 \mu \mathrm{g} / \mathrm{kg}$. The latest results of research conducted in Poland demonstrated its contents in the range from 61 to $397 \mu \mathrm{g} / \mathrm{kg}$ in ground coffee and from 152 to $830 \mu \mathrm{g} / \mathrm{kg}$ in instant coffee [Mojska \& Gielecińska, 2013]. The average percentage exposure of adults across Europe to acrylamide from roasted coffee, as a proportion of total food intake, was estimated at 0.5-39.9\% [EFSA, 2011; Mojska et al., 2010]. The chemical structure of acrylamide is presented in Figure 1. In 1994, it was classified by the International Agency for Research on Cancer (IARC) as "probably carcinogenic to humans (group 2A)" [WHO, 1994], and this definition is still valid. In rodent studies, acrylamide administered in drinking water showed a dose-related carcinogenic potential by inducing mammary and ovarian tumors [Beland et al., 2013]. In humans, dietary acrylamide exposure is much lower than this in animal studies, ranging from 12 to $39 \mu \mathrm{g} /$ day in European women [Freisling et al., 2013]. Large cohort studies allowed concluding that the usual food intake does not seem to be associated with an increased risk of breast cancer [Kotemori et al., 2018; Wilson et al., 2009] or ovarian cancer [Larsson et al., 2009; Obón-Santacana et al., 2016] induced by acrylamide. Also, no associations have been found between the intake of food high in acrylamide, including coffee, and an increased risk 
of premenopausal breast cancer development [Wilson et al., 2009]. Still, associations between acrylamide and ovarian or endometrial cancers cannot be completely excluded among high acrylamide consumers [Hogervorst et al., 2007; Pelucchi et al., 2015; Wilson et al., 2010].

\section{COFFEE AND SEX HORMONES}

The main female sex hormones are estrogen and progesterone. Natural estrogenic steroids are estrone (E1), estradiol (E2), and estriol (E3), of which estradiol is the most potent form. Ovarian-produced estradiol is the main estrogen in menstrual years, whereas estrone dominates in the menopause, produced in peripheral tissues from steroid precursor androstenedione. Unlike estriol, estrone can be converted to estradiol (Figure 2).

Estradiol exerts its biological effects through ERs located in the ovary, uterus, and breasts. Estrone and estradiol are hydroxylated by hepatic CYPs to catechol estrogen metabolites of various biological activities such as 2-pathway metabolites (2-hydroxyestradiol, 2-hydroxyestrone) and 4-pathway metabolites (4-hydroxyestradiol, 4-hydroxyestrone) (Figure 2). The 2-hydroxylated catechol estrogens are weak estrogens with potential anti-estrogenic activity [Ziegler et al., 2015]. Hydroxylated catechol estrogens are metabolized in the liver by catechol $O$-methyltransferase (COMT) to methoxylated estrogens such as 2-methoxyestradiol, 2-methoxyestrone and 4-methoxyestradiol, 4-methoxyestrone. The 2-methoxyestradiol exhibits anti-angiogenic, pro-apoptotic, and antitumor activities [Aquino-Gálvez et al., 2016; Gorska-Ponikowska et al., 2017]. Furthermore, a 16-pathway metabolite - 16 $\alpha$-hydroxyestradiol (estriol, E3) being a weak estrogen - is produced in small quantities in non-pregnant women via hepatic 16 $\alpha$-hydroxylation of estradiol and estrone by CYPs.

A growing number of studies have shown that plasma estrogens, especially free estradiol, which is unbound to the main estrogen carrier - sex hormone-binding globulin (SHBG) - are strongly associated with the risk of breast cancer development, mainly in the postmenopausal but also in the premenopausal women [Endogenous Hormones

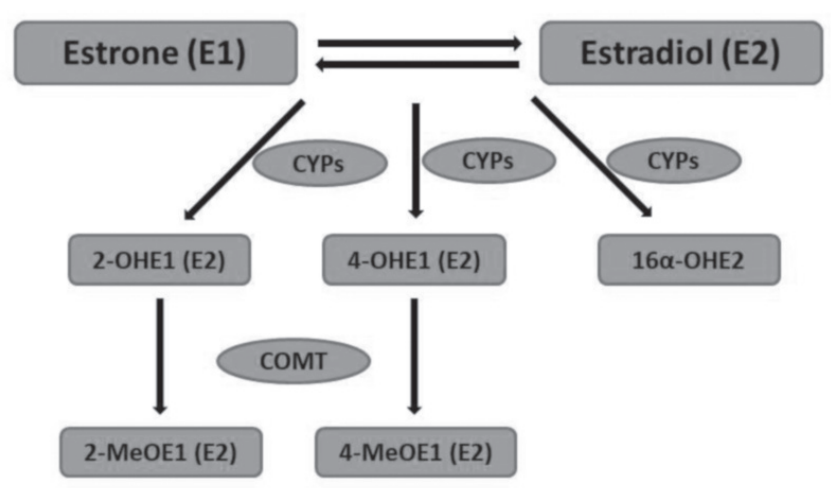

FIGURE 2. Metabolism of estrogen hormones. CYP - cytochrome P450, 2-OHE1 - 2-hydroxyestradiol, 4-OHE2 - 4-hydroxyestradiol, 16 $\alpha \mathrm{OHE} 2$ - 16 $\alpha$-hydroxyestradiol, 2-MeOE1 - 2-metoxyestrone, and 4-MeOE1 4-metoxyestrone. and Breast Cancer Collaborative Group, 2013; Folkerd \& Dowsett, 2013]. Only the free estradiol fraction, which is just a few per cent of the total plasma estradiol, can penetrate to a cell and stimulate steroid receptors. Conversely, estrogens transported by SHBG are in this bound form inactive, whereas increased SHBG concentrations are linked to the lower breast cancer risk.

Several studies provided evidence for associations between coffee or caffeine intake and sex hormone concentrations [Kotsopoulos et al., 2009; Nagata et al., 1998; Sisti et al., 2015]. Kotsopoulos et al. [2009] found that the total and free luteal estradiol concentrations in premenopausal women were inversely associated with coffee and caffeine intake. In contrast, the progesterone level was positively associated with caffeine but not with the intake of coffee. In turn, in the postmenopausal women, caffeine and coffee consumption was positively related to SHBG level. No relationship was found between coffee, caffeine or decaffeinated coffee and the concentrations of androgens or prolactin. This result suggests that coffee and caffeine may favorably modulate estrogen metabolism and protect against breast cancer both in pre- and postmenopausal women, but the mechanisms of this protection are entirely different.

A recent study which used data from 587 premenopausal women, participants of the Nurses' Health Study II, demonstrated that the estrogen metabolism could be influenced by coffee intake and by caffeine [Sisti et al., 2015]. This study measured mid-luteal urinary concentrations of 15 estrogens and estrogen metabolites and connected them to both caffeine and coffee intake ascertained on the basis of self-reported food frequency questionnaires. It was found that high ( $>4$ cups/day) versus low coffee intake ( $<4$ cups/week) was associated with higher excretion of 2-pathway estrogen metabolites of low estrogenic activity, i.e. 2-hydroxyestradiol and 2-hydroxyestron. Conversely, the 2-pathway metabolism was not affected by the consumption of decaffeinated coffee. However, the intake of at least 2 cups of decaffeinated coffee per day was associated with a significant reduction of 16-pathway metabolites with estrogenic activity, i.e. estriol and 17-epiestriol (17 $\alpha$-epimer of estriol), as compared to occasional coffee drinkers ( $<1-3$ cups/month). In turn, higher caffeine intake was associated with higher urinary concentrations of $16 \alpha$-hydroxyestrone and 16-epiestriol. This study concluded that the consumption of caffeine and coffee may differentially alter patterns of estrogen metabolism in the premenopausal women.

\section{COFFEE AND BREAST, ENDOMETRIAL, AND OVARIAN CANCERS IN WOMEN}

In vitro, coffee brews and some compounds present in coffee demonstrate antiproliferative activities in cancer cells [Tai et al., 2010]. Study results have shown that coffee compounds have an additive antiproliferation effect on cancer cell lines [Tai et al., 2010]. It has been suggested that selected coffee secondary metabolites may beneficially modulate several mechanisms of anti-cancer protection.

A number of studies have demonstrated an inverse relationship between coffee consumption and cancer risk [Arthur 
et al., 2018; Oh et al., 2015; Park et al., 2018]. Recently, one study threw light on the nature of associations between coffee consumption and some markers of immune system activation that may have a role in the development of cancer and chronic diseases. It was found that heavy coffee drinkers had lower circulating levels of host response proteins (IFN $\gamma, \mathrm{CX} 3 \mathrm{CL} 1 /$ fractalkine, CCL4/MIP-1 $\beta$ ), cell growth regulators (FGF-2), and proinflammatory cytokine sTNFRII than coffee abstainers [Loftfield et al., 2015].

Although breast cancer occurs in both sexes, it is most common in women. The current state of knowledge about breast, endometrial, and ovarian cancers in the context of coffee intake is discussed below.

\section{Breast cancer}

Cancers of the mammary glands are the most common invasive female cancers worldwide, and are also the leading cause of all cancer deaths in women [Ferlay et al., 2015]. The degree of morbidity increases with age and grows significantly after the age of 40 . Breast cancer incidence is associated with both modifiable and genetic factors. The modifiable risk factors include being overweight or obese, physical inactivity, and alcohol use. As estimated, these factors together contribute to $21 \%$ risk of developing breast cancer [Danaei et al., 2005]. The genetic factors are mostly associated with the presence of abnormal BRCA-l (breast cancer 1) and $B R C A-2$ (breast cancer-2) genes, which are normally involved in DNA repairing processes [Ford et al., 1998]. Mutations of these tumor-suppressor $B R C A$ genes may lead to an increased risk of breast cancer development.

In the $B R C A-1$ gene mutation carriers, high intake of caffeinated coffee amounting to 6 cups or more daily demonstrated a favorable effect by lowering breast cancer risk as compared to coffee abstainers [Nkondjock et al., 2006], an effect not observed in BRCA-2. Recent research has indicated that coffee and/or caffeine might have a chemopreventive effect, regardless of whether the women had the BRCA-l gene or not [Nikitina et al., 2015]. This effect was attributed to a more efficient repair processes of damaged DNA [Nikitina et al., 2015]. On the other hand, excessive consumption of coffee could have adverse effects. In female non-carriers of abnormal $B R C A$ genes, extremely large coffee consumption of 8 or more cups daily was associated with an increased risk of developing breast cancer [Bissonauth et al., 2009].

In women with defective $B R C A-1$, a protective effect seems to be associated with a mechanism of caffeine elimination through cytochrome P450 1A2 (CYP1A2), which is also common for the metabolism of estrogen. The protective effect of coffee in the BRCA- 1 abnormal gene carriers was limited to those females who had at least one $\mathrm{C}$ variant of cytochrome CYP1A2 [Kotsopoulos et al., 2007].

Until now, several dozen cohort and case-control studies have been devoted to the influence of coffee consumption on the incidence of breast cancer (Table 3). Most of the population studies showed no correlation between coffee drinking and breast cancer [Arthur et al., 2018; Bhoo-Pathy et al., 2010; Boggs et al., 2010; Fagherazzi et al., 2011; Gierach et al., 2012; Grosso et al., 2017a, b; Hashibe et al., 2015; Lukic et al., 2016; Yaghjyan et al., 2018], while some showed reduction
[Nilsson et al., 2010; Oh et al., 2015]. However, a 2018 dose-response meta-analysis of prospective cohort studies, which included more than a million women, showed that daily coffee consumption of 2 cups reduced the risk of breast cancer in postmenopausal women [Lafranconi et al., 2018]. Similarly, the earlier meta-analysis of 37 case-control studies showed a negative trend in postmenopausal women [Jiang et al., 2013].

Several studies assessed the risk of breast cancer based on the status of ER and progesterone receptor (PR). A Swedish Women's Lifestyle and Health cohort study demonstrated that coffee consumption and caffeine intake was negatively associated with the risk of developing ER positive and PR negative (ER+/PR-) breast cancer [Oh et al., 2015]. In turn, in a European Prospective Investigation into Cancer and $\mathrm{Nu}$ trition (EPIC) cohort study, a linear trend was observed for a lower risk of postmenopausal breast cancer with increasing caffeinated coffee intake for ER-/PR- cancer [Bhoo-Pathy et al., 2015]. Another Swedish study reported a lower risk of ER- breast cancer in postmenopausal high coffee consumers [Li et al., 2011]. Furthermore, a study undertaken in Sweden, which involved 1090 patients with invasive primary breast cancer, shed light on the effects of coffee on cancer progression [Rosendahl et al., 2015]. This study showed that smaller invasive primary tumors and lower prevalence of ER+ tumors were observed in moderate ( $2-4$ cups/day) to high ( $>5$ cups/ day) coffee consumers compared to low ( $<1 \mathrm{cup} /$ day) coffee consumers. Also, this moderate to high coffee intake was associated with a lower risk of breast cancer events in ER+ tumor patients treated with tamoxifen. These findings were translated into molecular and cellular levels [Rosendahl et al., 2015]. Coffee contains several biologically active substances which may interact with breast cancer cells to impair their cell-cycle progression and increase cancer cell death. Two of them are caffeine and caffeic acid. Both seem to sensitize breast cancer cells to tamoxifen and suppress growth of ER+ and ER- cells [Rosendahl et al., 2015]. In addition, caffeine reduces the number of ERs and cyclin D1 in ER+ cells, and also reduces insulin-like growth factor- 1 receptor (IGFIR) expression, which is implicated in carcinogenesis of some tumors, including breast cancer, and phosphorylated Akt (pAkt) levels in both ER+ and ER- cells, the enzyme which contributes to poor prognosis in breast cancer.

Recently, there has been a report from a case-control study showing that instant coffee, unlike brewed coffee, can increase the risk of breast cancer development [Lee et al., 2019]. This study concluded that there is a need for research on the effects of different types of coffee on the risk of breast cancer development.

\section{Ovarian cancer}

The number of studies on ovarian cancer and coffee and/ or caffeine is steadily increasing. So far, several prospective cohort and case-control studies have been performed. Recently, two meta-analyses have been conducted, one concerning 8 prospective studies and the other -20 case-control studies [Berretta et al., 2018; Shafiei et al., 2019].

Epidemiological studies are inconsistent in finding whether coffee, caffeine or decaffeinated coffee could be associated 
TABLE 3. Studies between 2010-2019 on coffee/caffeine intake and the risk of breast cancer.

\begin{tabular}{|c|c|c|c|c|c|}
\hline & $\begin{array}{l}\text { Name and design } \\
\text { of research }\end{array}$ & $\begin{array}{l}\text { Total number } \\
\text { of participants }\end{array}$ & $\begin{array}{l}\text { Number of breast } \\
\text { cancer (BC) cases }\end{array}$ & Major study outcomes & Reference \\
\hline Coffee & $\begin{array}{l}\text { EPIC-NL Cohort, } \\
\text { Netherlands }\end{array}$ & 27,323 & 681 & No association between coffee consumption and $\mathrm{BC}$ risk. & $\begin{array}{l}\text { Bhoo-Pathy } \\
\text { et al. [2010] }\end{array}$ \\
\hline $\begin{array}{l}\text { Coffee, } \\
\text { caffeine }\end{array}$ & $\begin{array}{c}\text { Black Women's } \\
\text { Health Study, USA, } \\
\text { cohort study }\end{array}$ & 52,062 & 1268 & $\begin{array}{l}\text { No association between coffee consumption or caffeine } \\
\text { intake and BC risk among African-American women. }\end{array}$ & $\begin{array}{l}\text { Boggs et al. } \\
\quad[2010]\end{array}$ \\
\hline Coffee & $\begin{array}{l}\text { Vasterbotten } \\
\text { Intervention } \\
\text { Project, Sweden, } \\
\text { prospective } \\
\text { cohort study }\end{array}$ & 64,603 & 3034 & $\begin{array}{c}\text { Boiled coffee } \geq 4 \text { versus }<1 \text { intakes/day associated with } \\
\text { a reduced risk of } \mathrm{BC}(\mathrm{HR}=0.52, \\
\text { CI } 0.30-0.88, \mathrm{p} \text { (trend) }=0.247) \text {. Increased risk } \\
\text { of premenopausal } \mathrm{BC} \text { for total coffee }(\mathrm{HR}=1.69, \\
\text { CI } 0.96-2.98, \mathrm{p} \text { (trend })=0.015) \text { and filtered coffee } \\
(\mathrm{HR}=1.76, \mathrm{CI} 1.04-3.00, \mathrm{p} \text { (trend })=0.045) \\
\text { Reduced risk of postmenopausal } \mathrm{BC} \text { for total coffee } \\
(\mathrm{HR}=0.60, \mathrm{CI} 0.39-0.93, \mathrm{p} \text { (trend })=0.006) \text { and filtered } \\
\text { coffee }(\mathrm{HR}=0.52, \mathrm{CI}=0.30-0.88, \mathrm{p} \text { (trend })=0.045) .\end{array}$ & $\begin{array}{l}\text { Nilsson et al. } \\
\text { [2010] }\end{array}$ \\
\hline
\end{tabular}

\begin{tabular}{lcccc}
\hline $\begin{array}{l}\text { Coffee, } \\
\text { caffeine }\end{array}$ & E3N cohort, France & 67,703 & 2868 & $\begin{array}{c}\text { No association between coffee consumption } \\
\text { or caffeine intake and BC risk. }\end{array}$ \\
\hline $\begin{array}{l}\text { Coffee, } \\
\text { caffeinated, } \\
\text { decaffeinated }\end{array}$ & $\begin{array}{c}\text { Health-AARP Diet } \\
\text { and Health Study } \\
\text { cohort, USA }\end{array}$ & 198,404 & $\begin{array}{c}\text { Fagherazzi } \\
\text { et al. [2011] }\end{array}$ \\
\hline
\end{tabular}

Coffee, Metaanalysis

decaffeinated of 37 case-control

coffee, caffeine and cohort studies

\begin{tabular}{|c|c|c|c|c|c|}
\hline $\begin{array}{l}\text { Coffee, } \\
\text { caffeinated } \\
\text { coffee, } \\
\text { decaffeinated } \\
\text { coffee }\end{array}$ & $\begin{array}{l}\text { European Prospective } \\
\text { Investigation into } \\
\text { Cancer and Nutrition } \\
\text { (EPIC) cohort study }\end{array}$ & 335,060 & $\begin{array}{l}1064 \\
\text { premenopausal, } \\
9134 \\
\text { postmenopausal }\end{array}$ & $\begin{array}{l}\text { Caffeinated and decaffeinated coffee were not associated } \\
\text { with premenopausal breast cancer. Caffeinated coffee } \\
\text { associated with lower risk of postmenopausal breast } \\
\text { cancer: adjusted HR }=0.90,95 \% \mathrm{CI}, 0.82-0.98 \text {, for } \\
\text { high } v s \text {. low consumption. Linear trend for lower BC } \\
\text { risk with increasing caffeinated coffee intake most } \\
\text { visible for estrogen and progesterone receptor negative } \\
\text { (ER-PR-) postmenopausal breast cancer }(\mathrm{P}=0.008) \text {. }\end{array}$ & $\begin{array}{l}\text { Bhoo-Pathy } \\
\text { et al. [2015] }\end{array}$ \\
\hline Coffee & $\begin{array}{l}\text { Swedish Women's } \\
\text { Lifestyle and Health } \\
\text { prospective } \\
\text { cohort study }\end{array}$ & 42,099 & 1395 & $\begin{array}{l}\text { Decreased RR of BC for }>3-4 \text { cups /day compared to } \\
1-2 \text { cups of coffee in pre- and postmenopausal women. }\end{array}$ & Oh et al. [2015] \\
\hline $\begin{array}{l}\text { Coffee, } \\
\text { caffeine }\end{array}$ & $\begin{array}{c}\text { Prostate, Lung, } \\
\text { Colorectal, } \\
\text { and Ovarian (PLCO) } \\
\text { cancer screening } \\
\text { trial, USA } \\
\end{array}$ & 50563 & 1698 & $\begin{array}{l}\text { No association between coffee } \\
\text { consumption, caffeine and BC risk. }\end{array}$ & $\begin{array}{l}\text { Hashibe et al. } \\
\quad[2015]\end{array}$ \\
\hline Coffee & $\begin{array}{l}\text { Norwegian Women } \\
\text { and Cancer } \\
\text { (NOWAC) Study, } \\
\text { population-based } \\
\text { prospective study }\end{array}$ & 91,767 & 3277 & No association between coffee consumption and BC risk. & $\begin{array}{l}\text { Lukic et al. } \\
\quad[2016]\end{array}$ \\
\hline Coffee & $\begin{array}{l}\text { Cancer Prevention } \\
\text { Study-II }\end{array}$ & 922,896 & 6113 & $\begin{array}{l}\text { In nonsmokers, a } 2 \text { cup/day increase in coffee } \\
\text { consumption inversely associated with death } \\
\text { from BC }(\mathrm{HR}=0.97 ; 95 \% \mathrm{CI}, 0.94-0.99) \text {. }\end{array}$ & $\begin{array}{l}\text { Gapstur et al. } \\
\text { [2017] }\end{array}$ \\
\hline $\begin{array}{l}\text { Coffee, } \\
\text { caffeinated } \\
\text { coffee, caffeine }\end{array}$ & $\begin{array}{l}\text { Canadian Study } \\
\text { of Diet, Lifestyle } \\
\text { and Health (CSDLH), } \\
\text { prospective case- } \\
\text { cohort study }\end{array}$ & 3120 & 922 & $\begin{array}{l}\text { Coffee and caffeine intake not associated with overall } \\
\text { BC risk. Tendency towards increased BC risk with } \\
\text { increasing levels of total coffee, caffeinated coffee and/or } \\
\text { caffeine in premenopausal and normal weight women. }\end{array}$ & $\begin{array}{l}\text { Arthur et al. } \\
\quad[2018]\end{array}$ \\
\hline Coffee & UK Biobank & $\begin{array}{c}126,182 \\
\text { postmenopausal } \\
\text { women }\end{array}$ & 2,636 & $\begin{array}{c}\text { Coffee consumption not associated with BC risk } \\
(\mathrm{HR}=1.00 ; 95 \% \mathrm{CI}, 0.91-1.11 \text { for } 2-3 \mathrm{cups} / \mathrm{day}, \\
\text { and } \mathrm{HR}=0.98,95 \% \text { CI } 0.87-1.10 \text { for } \geq 4 \mathrm{cups} / \mathrm{day} \text {. } \\
\text { No significant interaction between postmenopausal } \\
\text { hormone therapy and coffee consumption. }\end{array}$ & $\begin{array}{l}\text { Yaghjyan } \\
\text { et al. }[2018]\end{array}$ \\
\hline Coffee & $\begin{array}{l}\text { Dose-response } \\
\text { metaanalysis } \\
\text { of prospective } \\
\text { cohort studies }\end{array}$ & $1,068,098$ & 36,597 & $\begin{array}{l}2 \text { cups coffee/day associated with BC reduction } \\
\text { in postmenopausal women (RR } 0.90,95 \% \text { CI } 0.82-0.99) \text {. }\end{array}$ & $\begin{array}{l}\text { Lafranconi } \\
\text { et al. }[2018]\end{array}$ \\
\hline $\begin{array}{l}\text { Coffee instant, } \\
\text { coffee brewed }\end{array}$ & $\begin{array}{l}\text { Case-control study } \\
\text { in Hong Kong } \\
\text { Chinese Women }\end{array}$ & 2169 & 238 & $\begin{array}{l}\text { Instant coffee associated with increased } \mathrm{BC} \text { risk } \\
(\mathrm{AOR}=1.50,95 \% \mathrm{CI} 1.10-2.03) \text {; brewed coffee negatively } \\
\text { associated with } \mathrm{BC} \text { risk }(\mathrm{AOR}=0.48,95 \% \mathrm{CI} 0.28-0.82)\end{array}$ & Lee et al. [2019] \\
\hline
\end{tabular}

$\mathrm{BC}$ - breast cancer; ER - estrogen receptor; PR - progesterone receptor; RR - relative risk; HR - hazard ratio; CI - confidence interval; AOR - adjusted odds ratio. 
with the risk of ovarian cancer development. Research focuses on both, finding an increased as well as a decreased risk of developing ovarian cancer (Table 4). Some recent findings from the multinational EPIC cohort study, which included over 300,000 female participants, have shown increased mortality due to ovarian cancer in coffee drinkers [Gunter et al., 2017]. The remaining studies point rather to a decrease [Gosvig et al., 2015; Park et al., 2018] or lack of associations with ovarian cancer risk [Arthur et al., 2018; Berretta et al., 2018; Braem et al., 2012; Hashibe et al., 2015; Leung et al., 2016; Lukic et al., 2016; Ong et al., 2018; Shafiei et al., 2019].
Ong et al. [2018] studied genetic predisposition towards higher coffee intake and its implications associated with the risk of epithelial ovarian cancer development. However, they did not confirm this relationship.

Interesting results concerning coffee and ovarian cancer risk are presented in a meta-analysis of 20 case-control studies [Shafiei et al., 2019]. Although they did not establish any correlation between total coffee and caffeine intake, the authors found that decaffeinated coffee reduced the risk of ovarian cancer development. This may indicate an anticancer effect from other coffee ingredients than caffeine.

TABLE 4. Studies between 2010-2019 on coffee/caffeine intake and the risk of ovarian cancer.

\begin{tabular}{|c|c|c|c|c|c|}
\hline & $\begin{array}{l}\text { Name and type } \\
\text { of research }\end{array}$ & $\begin{array}{c}\text { Total number } \\
\text { of participants }\end{array}$ & $\begin{array}{c}\text { Number } \\
\text { of OC cases }\end{array}$ & Major study outcomes & Reference \\
\hline Coffee & $\begin{array}{l}\text { European Prospective } \\
\text { Investigation into } \\
\text { Cancer and Nutrition } \\
\text { (EPIC) prospective } \\
\text { cohort study } \\
\text { and metaanalysis }\end{array}$ & 330,849 & 1244 EOC cases & $\begin{array}{l}\text { No associations with } \mathrm{EOC} \text { risk } \mathrm{HR}=1.05(95 \% \mathrm{CI} \text {, } \\
0.75-1.46) \text { for the top quintile compared with no intake. }\end{array}$ & $\begin{array}{l}\text { Braem et al. } \\
\quad \text { [2012] }\end{array}$ \\
\hline $\begin{array}{l}\text { Coffee, } \\
\text { caffeine }\end{array}$ & $\begin{array}{l}\text { Danish case- } \\
\text { control study }\end{array}$ & 1293 & $\begin{array}{l}267 \text { OC, } 115 \\
\text { with borderline } \\
\text { OC }\end{array}$ & $\begin{array}{l}\text { Modest decrease in OC risk for coffee }(\mathrm{OR}=0.90,95 \% \mathrm{CI} \\
0.84-0.97 \text { per cup/day) and caffeine (from coffee and tea } \\
\text { combined) }(\mathrm{OR}=0.93,95 \% \mathrm{CI} 0.88-0.98 \text { per } 100 \mathrm{mg} / \text { day }) \text {. }\end{array}$ & $\begin{array}{l}\text { Gosvig et al. } \\
\text { [2015] }\end{array}$ \\
\hline $\begin{array}{l}\text { Coffee, } \\
\text { caffeine }\end{array}$ & $\begin{array}{l}\text { Prostate, Lung, } \\
\text { Colorectal, } \\
\text { and Ovarian cancer } \\
\text { screening trial, } \\
\text { cohort study }\end{array}$ & 97,334 & 162 & $\begin{array}{l}\text { No evidence of OC risk associated with coffee } \\
\text { consumption. Suggested risk for caffeine } \\
\text { intake for some specific OC quartiles. }\end{array}$ & $\begin{array}{l}\text { Hashibe et al. } \\
\text { [2015] }\end{array}$ \\
\hline $\begin{array}{l}\text { Coffee, } \\
\text { caffeinated } \\
\text { soft drinks }\end{array}$ & $\begin{array}{l}\text { population-based } \\
\text { Alberta and British } \\
\text { Columbia, Canada } \\
\text { case-control study }\end{array}$ & 2111 & $524 \mathrm{EOC}$ & $\begin{array}{l}\text { No evidence for risk of EOC associated } \\
\text { with coffee or caffeinated soft drinks. }\end{array}$ & $\begin{array}{l}\text { Leung et al. } \\
\quad[2016]\end{array}$ \\
\hline Coffee & $\begin{array}{l}\text { Norwegian Women } \\
\text { and Cancer } \\
\text { (NOWAC) Study, } \\
\text { population-based } \\
\text { prospective study }\end{array}$ & 91,767 & 446 & No association with OC risk. & $\begin{array}{l}\text { Lukic et al. } \\
\quad[2016]\end{array}$ \\
\hline Coffee & $\begin{array}{l}\text { EPIC (European } \\
\text { Prospective } \\
\text { Investigation } \\
\text { into Cancer } \\
\text { and Nutrition), } \\
\text { prospective } \\
\text { cohort study }\end{array}$ & 321,081 & 848 OC deaths & $\begin{array}{l}\text { Positive association between coffee and OC mortality } \\
\quad(\mathrm{HR}=1.12,95 \% \text { CI } 1.02-1.23 \text {, P-trend } 0.001) .\end{array}$ & $\begin{array}{l}\text { Gunter et al. } \\
\text { [2017] }\end{array}$ \\
\hline $\begin{array}{l}\text { Coffee, } \\
\text { caffeinated } \\
\text { coffee, } \\
\text { caffeine }\end{array}$ & $\begin{array}{l}\text { Canadian Study } \\
\text { of Diet, Lifestyle } \\
\text { and Health (CSDLH), } \\
\text { prospective case- } \\
\text { cohort study }\end{array}$ & 2826 & 104 & $\begin{array}{l}\text { Coffee and caffeine intake not } \\
\text { associated with OC overall risk. }\end{array}$ & $\begin{array}{l}\text { Arthur et al. } \\
\text { [2018] }\end{array}$ \\
\hline $\begin{array}{l}\text { Coffee, } \\
\text { caffeine }\end{array}$ & $\begin{array}{l}\text { Ovarian Cancer } \\
\text { Association } \\
\text { Consortium } \\
\text { (OCAC), Europe }\end{array}$ & - & $44,062 \mathrm{EOC}$ & $\begin{array}{l}\text { Single nucleotide polymorphisms (SNP) rs6968865 from } \\
\text { the } A H R \text { gene and rs2472297 from the CYPIA2 gene, } \\
\text { associated with coffee consumption. } \\
\text { No evidence on strong association between EOC risk } \\
\text { and genetically predicted coffee or caffeine levels. }\end{array}$ & Ong et al. [2018] \\
\hline Coffee & $\begin{array}{c}\text { Multiethnic Cohort } \\
\text { Study in Hawaii } \\
\text { and Los Angeles, USA }\end{array}$ & 167,720 & 1795 & $\begin{aligned} \text { Reduced OC risk with HR } & =0.33(95 \% \\
\text { CI } 0.17-0.65) ; \text { Ptrend } & =0.007\end{aligned}$ & Park et al. [2018] \\
\hline Coffee & $\begin{array}{l}\text { Metaanalysis } \\
\text { of } 8 \text { prospective } \\
\text { cohort studies }\end{array}$ & 787,076 & 3541 & Coffee intake not associated with OC risk. & $\begin{array}{l}\text { Berretta et al. } \\
\quad[2018]\end{array}$ \\
\hline $\begin{array}{l}\text { Coffee, } \\
\text { caffeine, } \\
\text { caffeinated } \\
\text { coffee, } \\
\text { decaffeinated } \\
\text { coffee }\end{array}$ & $\begin{array}{l}\text { Metaanalysis } \\
\text { of } 20 \text { case- } \\
\text { control studies }\end{array}$ & 40,140 & 8568 & $\begin{array}{l}\text { No significant association between total coffee intake } \\
\text { or caffeine and OC risk. Inverse association between } \\
\text { decaffeinated coffee intake and OC risk }(\mathrm{OR}=0.72,95 \% \mathrm{CI} \\
0.58-0.90) \text {. No association with caffeinated coffee. }\end{array}$ & $\begin{array}{l}\text { Shafiei et al. } \\
\text { [2019] }\end{array}$ \\
\hline
\end{tabular}

OC - ovarian cancer, EOC - epithelial ovarian cancer, RR - relative risk, HR - hazard ratio, OR - odds ratio, $\mathrm{CI}$ - confidence interval. 


\section{Endometrial cancer}

Endometrial cancer (EC) is the most common uterine cancer, which is derived from the endometrium, the inner lining of the uterus. The risk factors for endometrial cancer include obesity, long-term stimulation by increased levels of estrogen, high blood pressure, diabetes, early age of menarche, nulliparity, and late menopause [Ali, 2014; Raglan et al., 2019]. Postmenopausal women aged 60-70 years with excessive body weight are more predisposed to this cancer. After the menopause, gonadal production of estrogen and progesterone decreases, and androstenedione - another hormone produced by ovaries, is converted by adipose tissue to estrone in obese women. Continuous stimulation of endometrium by estrone without progesterone secretion leads to uncontrolled proliferation of endometrial tissue [Michels et al., 2019]. Most cases of endometrial cancer fell into this cause-and-effect pattern (Type I EC); however, there are EC cases (10-20\%) which are non-estrogen dependent (Type II EC) [Doll et al., 2008]. Whereas molecular characteristics describe Type EC I as endometrial endometrioid adenocarcinomas (EEAs) with or without squamous differentiation and in most cases well differentiated, whereas Type II tumors are high-grade serous papillary or clear cell carcinomas [Doll et al., 2008].

Relatively many studies concern the consumption of total coffee, caffeinated, and decaffeinated coffee, and caffeine in relation to the risk of EC (Table 5). At least five metaanalyses of cohort and case-control studies were carried out

TABLE 5. Studies between 2010-2019 on coffee/caffeine intake and the risk of endometrial cancer.

\begin{tabular}{|c|c|c|c|c|c|}
\hline & $\begin{array}{c}\text { Name and type } \\
\text { of research }\end{array}$ & $\begin{array}{c}\text { Total number } \\
\text { of participants }\end{array}$ & $\begin{array}{c}\text { Number } \\
\text { of EC cases }\end{array}$ & Major study outcomes & Reference \\
\hline $\begin{array}{l}\text { Coffee, } \\
\text { coffee } \\
\text { caffeinated, } \\
\text { coffee } \\
\text { decaffeinated }\end{array}$ & $\begin{array}{l}\text { Women's } \\
\text { Health Initiative } \\
\text { Observational } \\
\text { Study, USA }\end{array}$ & 45,696 & $\begin{array}{c}427 \\
\text { postmenopausal } \\
\text { women }\end{array}$ & $\begin{array}{l}\text { No association between coffee consumption and EC risk. } \\
\text { No associations among normal-weight and overweight } \\
\text { women for total coffee and caffeinated coffee. }\end{array}$ & Giri et al. [2011] \\
\hline $\begin{array}{l}\text { Coffee, } \\
\text { coffee } \\
\text { caffeinated, } \\
\text { coffee } \\
\text { decaffeinated }\end{array}$ & $\begin{array}{c}\text { Nurses' Health } \\
\text { Study (NHS), USA }\end{array}$ & 67,470 & 672 & $\begin{array}{c}<4 \text { cups of coffee/day not associated with EC risk. } \\
\text { Multivariable } \mathrm{RR}=0.75,95 \% \mathrm{CI} 0.57-0.97 ; \mathrm{P}(\text { trend })= \\
0.02)>4 \text { cups/day } v s .>1 \text { cup/day. For } \geq 4 \text { vs. }<1 \text { cup } / \mathrm{d} \\
\mathrm{RR}=0.70,95 \% \mathrm{CI}=0.51-0.95 \text { for caffeinated coffee. For } \\
\text { decaffeinated coffee consumption, a suggestive inverse } \\
\text { association for } 2 \text { or more cups/day } v \text { s. }<1 \text { cup } / \text { month. }\end{array}$ & Je et al. [2011] \\
\hline Coffee & $\begin{array}{l}\text { Meta-analysis } \\
\text { of } 10 \text { case-control } \\
\text { and } 6 \text { cohort studies }\end{array}$ & - & 6,628 & 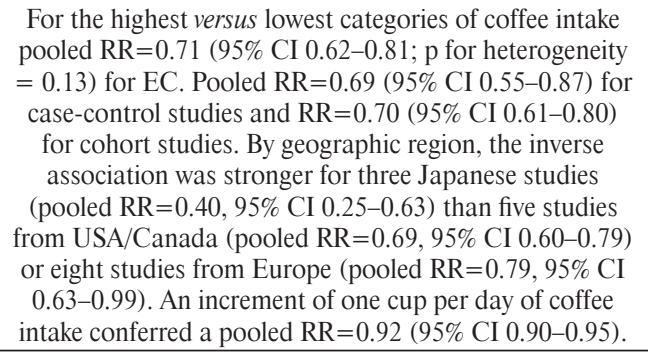 & $\begin{array}{c}\text { Je \& Giovanucci, } \\
\text { [2012] }\end{array}$ \\
\hline $\begin{array}{l}\text { Coffee } \\
\text { caffeinated, } \\
\text { decaffeinated, } \\
\text { caffeine }\end{array}$ & $\begin{array}{l}\text { Prospective cohort } \\
\text { Iowa Women's Health } \\
\text { Study (IWHS), USA }\end{array}$ & 23,356 & $\begin{array}{c}471 \text { Type I, } \\
71 \text { Type II EC } \\
\text { postmenopausal } \\
\text { women }\end{array}$ & $\begin{array}{l}\text { Type I EC (age range at diagnosis } 57.2-89.5 \text { years) } \\
\text { significantly associated with caffeinated }(\mathrm{RR}=0.65 \text { for } 4+ \\
\text { cups per day } v s . \leq 1 \text { cup per month, } 95 \% \text { CI } 0.47-0.89) \text {, } \\
\text { but not for decaffeinated coffee intake. No associations } \\
\text { with tea, cola or chocolate, or for Type II EC. Inverse } \\
\text { association with caffeinated coffee in women with } \\
\text { BMI }>30 \mathrm{~kg} / \mathrm{m}^{2}(\mathrm{RR}=0.56 ; 95 \% \text { CI: } 0.36-0.89) \text {. }\end{array}$ & $\begin{array}{l}\text { Uccella et al. } \\
\text { [2013] }\end{array}$ \\
\hline $\begin{array}{l}\text { Coffee, } \\
\text { caffeine }\end{array}$ & $\begin{array}{l}\text { Swedish Women's } \\
\text { Lifestyle and Health } \\
\text { cohort study }\end{array}$ & 42,270 & 144 & $\begin{array}{l}\text { Similar mean daily coffee consumption in women } \\
\text { with and without EC ( } 549 \mathrm{~g} \text { vs. } 547 \mathrm{~g} \text { ) and caffeine } \\
\text { intake ( } 405 \text { vs. } 406 \mathrm{mg} \text { ). No association } \\
\text { between coffee consumption or caffeine intake } \\
\text { and EC risk among middle-aged women. }\end{array}$ & $\begin{array}{l}\text { Weiderpass } \\
\text { et al. [2014] }\end{array}$ \\
\hline Coffee & $\begin{array}{l}\text { Norwegian Women } \\
\text { and Cancer } \\
\text { (NOWAC) Study, } \\
\text { population-based } \\
\text { prospective study }\end{array}$ & 97,926 & 462 & $\begin{array}{l}\text { Significant risk reduction found for } \geq 8 \text { cups/day of coffee } \\
\mathrm{HR}=0.52 \text { ( } 95 \% \text { CI } 0.34-0.79) \text { in multivariate adjustment } \\
\text { model. No significant dose-response relationship. } \\
\text { No significant heterogeneity in risk found for filtered } \\
\text { and boiled coffee. Reduced EC risk in subgroup } \\
\text { analyses among participants who drank } \geq 8 \text { cups } / \text { day } \\
\text { and had BMI } \geq 25 \mathrm{~kg} / \mathrm{m}^{2}, \text { and in current smokers. }\end{array}$ & $\begin{array}{l}\text { Gavrilyuk } \\
\text { et al. [2014] }\end{array}$ \\
\hline $\begin{array}{l}\text { Coffee, } \\
\text { caffeine }\end{array}$ & $\begin{array}{c}\text { Prostate, Lung, } \\
\text { Colorectal, } \\
\text { and Ovarian (PLCO) } \\
\text { cancer screening } \\
\text { trial, USA } \\
\end{array}$ & 32,293 & 257 & $\begin{array}{c}\mathrm{RR}=0.69(95 \% \text { CI } 0.52-0.91) \text { for coffee } \\
\text { intake } \geq 2 \text { cups per day. Caffeine not associated } \\
\text { with cancer risk in a dose-response manner. }\end{array}$ & $\begin{array}{l}\text { Hashibe et al. } \\
\text { [2015] }\end{array}$ \\
\hline Coffee & $\begin{array}{l}\text { UK Million Women } \\
\text { prospective study } \\
\text { and meta-analysis }\end{array}$ & 560,356 & 4067 & $\begin{array}{l}\text { No significant association between EC risk } \\
\text { and consumption of coffee. Weak association for } \\
\text { coffee consumption with EC in prospective studies. }\end{array}$ & $\begin{array}{l}\text { Yang et al. } \\
\text { [2015] }\end{array}$ \\
\hline
\end{tabular}


TABLE 5. Continued

\begin{tabular}{|c|c|c|c|c|c|}
\hline & $\begin{array}{c}\text { Name and type } \\
\text { of research }\end{array}$ & $\begin{array}{l}\text { Total number } \\
\text { of participants }\end{array}$ & $\begin{array}{c}\text { Number } \\
\text { of EC cases }\end{array}$ & Major study outcomes & Reference \\
\hline Coffee & $\begin{array}{l}\text { European Prospective } \\
\text { Investigation into } \\
\text { Cancer and Nutrition } \\
\text { (EPIC) and Nurses } \\
\text { Health Studies } \\
\text { (NHS/NHSII) }\end{array}$ & $\begin{array}{l}539,237 \\
(301,107 \text { (EPIC; } \\
\text { 238,130 NHS/ } \\
\text { NHSII) }\end{array}$ & $\begin{array}{c}2834 \\
\text { (1303 EPIC; } \\
1531 \text { NHS/NHSII) }\end{array}$ & $\begin{array}{l}\text { Multivariate-adjusted comparisons of extreme categories } \\
\text { of intake: EPIC, median intake } 750 \mathrm{~g} / \text { day } v s .8 .6 \mathrm{~g} / \\
\text { day; } \mathrm{HR}=0.81 \text { (95\% CI } 0.68-0.97), \text { Ptrend }=0.09 \\
\text { NHS/NHSII, median intake } 1067 \mathrm{~g} / \text { day } v \text { s. none; } \\
\mathrm{HR}=0.82 \text { (95\% CI } 0.70-0.96), \text { Ptrend }=0.04\end{array}$ & $\begin{array}{c}\text { Merritt et al. } \\
{[2015]}\end{array}$ \\
\hline $\begin{array}{l}\text { Coffee, } \\
\text { caffeinated } \\
\text { coffee, } \\
\text { decaffeinated } \\
\text { coffee, caffeine }\end{array}$ & $\begin{array}{l}\text { Dose-response } \\
\text { meta-analysis } \\
\text { of } 13 \text { prospective } \\
\text { cohort studies }\end{array}$ & $1,534,039$ & 10,100 & $\begin{array}{c}\mathrm{RR}=0.80(95 \% \text { CI } 0.74-0.86) \text { for total coffee consumption } \\
(\mathrm{RR}=0.60(95 \% \text { CI } 0.50-0.72) \text { in EC women never treated } \\
\text { with hormones, } \mathrm{R}=0.57(95 \% \text { CI } 0.46-0.71) \text { in overweight/ } \\
\text { obese. Overall RR }=0.66(95 \% \text { CI } 0.52-0.84) \text { for } \\
\text { caffeinated and RR }=0.77(95 \% \text { CI } 0.63-0.94) \text { for } \\
\text { decaffeinated coffee. Linear dose-response relationship } \\
\text { for coffee, caffeinated coffee, decaffeinated coffee } \\
\text { and caffeine intake. EC risk decreased by } 5 \% \text { for every } \\
1 \text { cup/day of coffee, } 7 \% \text { for every } 1 \text { cup/day of caffeinated } \\
\text { coffee, } 4 \% \text { for every } 1 \text { cup/day of decaffeinated coffee, } \\
\text { and } 4 \% \text { for every } 100 \mathrm{mg} \text { of caffeine intake/day. }\end{array}$ & $\begin{array}{c}\text { Zhou et al. } \\
\text { [2015] }\end{array}$ \\
\hline Coffee & $\begin{array}{l}\text { Dose-response } \\
\text { meta-analysis } \\
\text { of } 12 \text { prospective } \\
\text { cohort studies }\end{array}$ & $1,404,541$ & 10,548 & $\begin{array}{l}4 \text { cups coffee } / \text { day associated with } \mathrm{RR}=0.80,95 \% \\
\text { CI } 0.72-0.89 \text { ) for } \mathrm{EC} \text { risk and with } \mathrm{RR}=0.76,95 \% \\
\text { CI } 0.69-0.83 \text { ) for postmenopausal } \mathrm{EC} \text { risk. }\end{array}$ & $\begin{array}{l}\text { Lafranconi } \\
\text { et al. [2017] }\end{array}$ \\
\hline $\begin{array}{l}\text { Coffee, } \\
\text { caffeinated } \\
\text { coffee, caffeine }\end{array}$ & $\begin{array}{l}\text { Canadian Study } \\
\text { of Diet, Lifestyle } \\
\text { and Health (CSDLH), } \\
\text { prospective case- } \\
\text { cohort study }\end{array}$ & 2608 & 180 & $\begin{array}{c}\text { For coffee cup increase } \mathrm{HR}=0.88(95 \% \mathrm{CI} \\
0.79-0.95), \text { for caffeinated coffee cup increase } \\
\mathrm{HR}=0.88(95 \% \text { CI } 0.80-0.96) \text {, for } 100 \mathrm{mg} \text { caffeine } \\
\text { increase } \mathrm{HR}=0.93(95 \% \text { CI } 0.87-0.99) .\end{array}$ & $\begin{array}{c}\text { Arthur et al. } \\
\text { [2018] }\end{array}$ \\
\hline Coffee & $\begin{array}{l}\text { Meta-analysis } \\
\text { of } 12 \text { cohort } \\
\text { studies and } 8 \text { case- } \\
\text { control studies }\end{array}$ & - & $\begin{array}{c}11,663 \text { cases } \\
\text { in cohort studies } \\
\text { and } 2,746 \text { cases } \\
\text { in case-control } \\
\text { studies }\end{array}$ & $\begin{array}{c}\text { For highest } v s \text {. lowest coffee intake summary } \\
\text { RR }=0.74(95 \% \text { CI } 0.68-0.81 ; \text { p heterogeneity }=0.09 \text {, } \\
\text { I } 2=32 \%) \text {, for cohort studies RR }=0.78(95 \% \\
\text { CI } 0.71-0.85 ; \text { p heterogeneity }=0.14, \mathrm{I} 2=31.9 \%) \text {, } \\
\text { for case-control studies } \mathrm{RR}=0.63(95 \% \mathrm{CI} 0.53-0.76 \text {; } \\
\text { p heterogeneity }=0.57, \mathrm{I} 2=0 \%) \text {. One-cup increment } \\
\text { day associated with } 3 \% \text { risk reduction }(95 \% \mathrm{CI} 2-4 \%) \\
\text { in cohort studies and } 12 \%(95 \% \text { CI } 5-18 \%) \text { in case-control } \\
\text { studies. After pooling the results from } 5 \text { cohort studies that } \\
\text { included BMI, the association remained significant only } \\
\text { in women with BMI }>30(\mathrm{RR}=0.71,95 \% \text { CI } 0.61-0.81) \text {. }\end{array}$ & $\begin{array}{l}\text { Lukic et al. } \\
\text { [2018] }\end{array}$ \\
\hline
\end{tabular}

$\mathrm{EC}$ - endometrial cancer, $\mathrm{RR}$ - relative risk, $\mathrm{HR}$ - hazard ratio, $\mathrm{CI}$ - confidence interval, $\mathrm{BMI}$ - body mass index.

between 2010 and 2019 [Je \& Giovannucci, 2012; Lafranconi et al., 2017; Lukic et al., 2018; Yang et al., 2015; Zhou et al., 2015]. In cohort studies, high coffee intake compared to no intake was associated with a lower EC risk [Merritt et al., 2015]. Similar findings were reported for coffee, caffeinated coffee, and caffeine [Arthur et al., 2018]. Intake of four or more cups of coffee a day [Je et al., 2011], or more recently consumption of two or more cups a day [Hashibe et al., 2015], was associated with lower EC risk, but some research showed no conclusive association [Weiderpass et al., 2014]. Coffee intake was found to be particularly beneficial in overweight or obese women [Friberg et al., 2009; Gavrilyuk et al., 2014; Lukic et al., 2018; Uccella et al., 2013; Zhou et al., 2015]. Several studies have indicated that coffee intake might be associated with a decreased cancer risk in obese postmenopausal women [Giri et al., 2011, Uccella et al., 2013]. Caffeinated coffee consumption seems to have an advantage over decaffeinated coffee [Zhou et al., 2015].

In one study, coffee was examined as a contributor to the dietary antioxidant activity (DAA) of EC patients. Coffee-related DAA was found to be inversely associated with the overall $\mathrm{EC}$ risk $(\mathrm{OR}=0.87$, CI 0.77-0.99) [Rossi et al., 2016]. Such association, however, was weak for DAA with no coffee intake included. The above research points to the role of coffee as a dietary factor with the strongest impact on DAA, whereas the highest DAA quartile is associated with the lowest risk of $\mathrm{EC}(\mathrm{OR}=0.75$, CI 0.52-1.08).

The evidence supports the association between coffee and decreased EC risk in postmenopausal women. The mechanism of this association is not clearly understood. One line of evidence points to diabetes, which is a well-established factor in EC development. Most recently, the risk of developing EC has been linked to high fasting insulin, C-peptide and HOMA-IR values, which are the parameters used to assess $\beta$-cell function and insulin resistance [Hernandez et al., 2015]. Coffee intake combined with hormone-replacement therapy (HRT) seems to sensitize cell receptors to insulin and decrease insulin resistance in postmenopausal women [Catalano et al., 2008]. Insulin resistance correlates directly with body mass index (BMI), and coffee intake increases insulin sensitivity in overweight women [Catalano et al., 2008].

\section{CONCLUSIONS}

As shown in publications cited in this paper, coffee is composed of multiple chemical compounds, that vary according to such factors as: type of beans (Arabica, Robusta), roasting process, preparation (instant coffee) and brewing 
method. Therefore, their content in a coffee cup can vary greatly. Most long-term observational studies were planned from the viewpoint of consumption of total, caffeinated, decaffeinated coffee, and caffeine, but they took no account of the size of coffee portions and the content of biologically active substances, which may vary several times between cups. Such studies generally do not distinguish between ground roasted coffee and instant coffee. A recent case-control study has raised this issue and showed a positive relationship with breast cancer [Lee et al., 2019]. For all these reasons, it is difficult to determine the appropriate dose and type of coffee that would be most effective in preventing cancer. An issue that has not yet been studied is the question of the additives with which coffee is consumed, such as milk or sugar, and how they can affect bioavailability of coffee compounds, as has been shown for tea [Korir et al., 2014]. Clinical trials offer more standardized conditions of research. However, in the case of cancer, long-term clinical trials are not feasible. In turn, long-term observational studies are in some cases ambiguous as regards the effect of coffee consumption, showing a positive, negative or no relationship between coffee consumption and breast, ovarian or endometrial cancer. In general, most studies and metaanalyses indicate that there is no clear correlation between coffee and breast cancer or ovarian cancer. However, some subgroups of women can benefit from coffee consumption. This is the case for post-menopausal women with regard to the risk of breast cancer and obese women with regard to the risk of endometrial cancer [Lafranconi et al., 2018; Lukic et al, 2018; Zhou et al., 2015]. The situation is unclear in the case of ovarian cancer, where the effect of coffee is generally not observed, but in the case of decaffeinated coffee the opposite relationship may exist [Shafiei et al., 2019]. Further research should therefore be targeted at them with clearly defined portion sizes and preparation methods. In addition, more attention should be paid to whether or not cancer is hormone-dependent and whether there is a genetic predisposition to breast, ovarian or endometrial cancer. Many lifestyle factors such as smoking, improper diet, excessive consumption of alcohol, contribute to the risk of developing cancer. Future research should pay attention to selecting participants in order to minimize the possible influence of confounding factors [Grosso et al., 2016].

Coffee is an important dietary source of biologically active compounds with the caffeine being the most abundant. In vitro and in vivo studies suggest that various classes of secondary metabolites of coffee may beneficially modulate several mechanisms of anti-cancer protection. It would be interesting to examine whether the compounds present in coffee have a synergistic effect and whether caffeine is indeed one of the most important substances that have an anti-cancer effect. Recent studies show that decaffeinated coffee can also exhibit these properties [Shafiei et al., 2019], indicating that other coffee compounds are important as well. The available literature on human studies related to single coffee components is limited to caffeine and therefore this research topic is needed to be developed. Furthermore, the metabolism of many coffee compounds in the body requires better characterization. This applies especially to phenolics, which undergo microbiologi- cal transformation in the intestine. And yet, some coffee compounds, such as lignans and trigonelline, have an estrogenic activity, which can be important when studying hormone-dependent cancers.

There are some strengths and limitations of this review. Its strength and at the same time its limitation is the timeperiod in which literature was sought, which allowed for the collection of the latest publications, but omitted most of the publications before that period. However, in the case of observational studies, most of the previous case-control and epidemiological studies have been analyzed in recent meta-analyses. On the other hand, the search was limited to two electronic databases, thus some studies may not have been included in this review.

This literature review shows that, despite extensive knowledge of coffee and its effects on human health, there are still many open questions to explore in relation to breast, ovarian, and endometrial cancer. Important issues for future research are to better understand the anti-cancer mechanisms of coffee compounds, especially of diterpenes, trigonelline and phenolics, and to undertake research that would focus on specific target groups, taking into account both the different methods of coffee preparation and lifestyle factors that may interfere with the results.

\section{CONFLICTS OF INTEREST}

The authors declare no conflict of interest.

\section{REFERENCES}

1. Acidri, R., Sawai, Y., Sugimoto, Y., Handa, T., Sasagawa, D., Masunaga, T., Yamamoto, S., Nishihara, E. (2020). Phytochemical profile and antioxidant capacity of coffee plant organs compared to green and roasted coffee beans. Antioxidants (Basel), 9(2), pii: E93.

2. Ali, A.T. (2014). Reproductive factors and the risk of endometrial cancer. International Journal of Gynecological Cancer, 24(3), 384-393.

3. Arthur, R., Kirsh, V.A., Rohan, T.E. (2018). Associations of coffee, tea and caffeine intake with risk of breast, endometrial and ovarian cancer among Canadian women. Cancer Epidemiology, 56, 75-82.

4. Allred, K.F., Yackley, K.M., Vanamala, J., Allred, C.D. (2009). Trigonelline is a novel phytoestrogen in coffee beans. Journal of Nutrition, 139(10), 1833-1838.

5. Angeloni, S., Navarini, L., Sagratini, G., Torregiani, E., Vittori, S., Caprioli, G. (2018). Development of an extraction method for the quantification of lignans in espresso coffee by using HPLCMS/MS triple quadrupole. Journal of Mass Spectrometry, 53(9), 842-848.

6. Aquino-Gálvez, A., González-Ávila, G., Delgado-Tello, J., Castillejos-López, M., Mendoza-Milla, C., Zúñiga, J., Checa, M., Maldonado-Martínez, H.A., Trinidad-López, A., Cisneros, J., Torres-Espíndola, L.M., Hernández-Jiménez, C., Sommer, B., Cabello-Gutiérrez, C., Gutiérrez-González, L.H. (2016). Effects of 2-methoxyestradiol on apoptosis and HIF- $1 \alpha$ and HIF-2 $\alpha$ expression in lung cancer cells under normoxia and hypoxia. Oncology Reports, 35(1), 577-583. 
7. Bakuradze, T., Lang, R., Hofmann, T., Eisenbrand, G., Schipp, D., Galan, J., Richling, E. (2015). Consumption of a dark roast coffee decreases the level of spontaneous DNA strand breaks: a randomized controlled trial. European Journal of Nutrition, 54(1), 149-156.

8. Barnung, R.B., Nøst, T.H., Ulven, S.M., Skeie, G., Olsen, K.S. (2018). Coffee consumption and whole-blood gene expression in the Norwegian women and cancer post-genome cohort. Nutrients, 10(8), art. no. E1047.

9. Beland, F.A., Mellick, P.W., Olson, G.R., Mendoza, M.C., Marques, M.M., Doerge, D.R. (2013). Carcinogenicity of acrylamide in $\mathrm{B} 6 \mathrm{C} 3 \mathrm{~F}(1)$ mice and $\mathrm{F} 344 / \mathrm{N}$ rats from a 2-year drinking water exposure. Food Chemistry and Toxicology, 51, 149-159.

10. Berretta, M., Micek, A., Lafranconi, A., Rossetti, S., Di Francia, R., De Paoli, P., Rossi, P., Facchini, G. (2018). Coffee consumption is not associated with ovarian cancer risk: a dose-response meta-analysis of prospective cohort studies. Oncotarget, 9(29), 20807-20815.

11. Bhoo-Pathy, N., Peeters, P.H., Uiterwaal, C.S., Bueno-de-Mesquita, H.B., Bulgiba, A.M., Bech, B.H., Overvad, K., Tjønneland, A., Olsen, A., Clavel-Chapelon, F., Fagherazzi, G., Perquier, F., Teucher, B., Kaaks, R., Schütze, M., Boeing, H., Lagiou, P., Orfanos, P., Trichopoulou, A., Agnoli, C., Mattiello, A., Palli, D., Tumino, R., Sacerdote, C., van Duijnhoven, F.J., Braaten, T., Lund, E., Skeie, G., Redondo, M.L., Buckland, G., Pérez, M.J., Chirlaque, M.D., Ardanaz, E., Amiano, P., Wirfält, E., Wallström, P., Johansson, I., Nilsson, L.M., Khaw, K.T., Wareham, N., Allen, N.E., Key, T.J., Rinaldi, S., Romieu, I., Gallo, V., Riboli, E., van Gils, C.H. (2015). Coffee and tea consumption and risk of preand postmenopausal breast cancer in the European Prospective Investigation into Cancer and Nutrition (EPIC) cohort study. Breast Cancer Research, 17(1), art. no. 15

12. Bhoo Pathy, N., Peeters, P., van Gils, C., Beulens, J.W., van der Graaf, Y., Bueno-de-Mesquita, B., Bulgiba, A., Uiterwaal, C.S. (2010). Coffee and tea intake and risk of breast cancer. Breast Cancer Research and Treatment, 121 (2), 461-467.

13. Bissonauth, V., Shatenstein, B., Fafard, E., Maugard, C., Robidoux, A., Narod, S., Ghadirian, P. (2009). Risk of breast cancer among French-Canadian women, noncarriers of more frequent BRCA1/2 mutations and consumption of total energy, coffee, and alcohol. Breast Journal, 15(Suppl 1), S63-71.

14. Boettler, U., Sommerfeld, K., Volz, N., Pahlke, G., Teller, N., Somoza, V., Lang, R., Hofmann, T., Marko, D. (2011). Coffee constituents as modulators of Nrf2 nuclear translocation and ARE (EpRE)-dependent gene expression. Journal of Nutritional Biochemistry, 22(5), 426-440.

15. Boggs, D.A., Palmer, J.R., Stampfer, M.J., Spiegelman, D., Adams-Campbell, L.L., Rosenberg, L. (2010). Tea and coffee intake in relation to risk of breast cancer in the Black Women's Health Study. Cancer Causes \& Control, 2 I (11), 1941-1948.

16. Braem, M.G., Onland-Moret, N.C., Schouten, L.J., Tjønneland, A., Hansen, L., Dahm, C.C., Overvad, K., Lukanova, A., Dossus, L., Floegel, A., Boeing, H., Clavel-Chapelon, F., Chabbert-Buffet, N., Fagherazzi, G., Trichopoulou, A., Benetou, V., Goufa, I., Pala, V., Galasso, R., Mattiello, A., Sacerdote, C., Palli, D., Tumino, R., Gram, I.T., Lund, E., Gavrilyuk, O., Sánchez, M.J., Quirós, R., Gonzales, C.A., Dorronsoro, M., Castaño, J.M., Gurrea, A.B., Idahl, A., Ohlson, N., Lundin, E., Jirstrom, K,, Wirfalt, E., Allen, N.E., Tsilidis, K.K., Kaw, K.T., Bueno-de-
-Mesquita, H.B., Dik, V.K., Rinaldi, S., Fedirko, V., Norat, T., Riboli, E., Kaaks, R., Peeters, PH. (2012). Coffee and tea consumption and the risk of ovarian cancer: a prospective cohort study and updated meta-analysis. American Journal of Clinical Nutrition, 95(5), 1172-1181.

17. Bray, F., Ferlay, J., Soerjomataram, I., Siegel, R.L., Torre, L.A., Jemal, A. (2018). Global cancer statistics 2018: GLOBOCAN estimates of incidence and mortality worldwide for 36 cancers in 185 countries. CA: A Cancer Journal for Clinicians, 68(6), 394-424.

18. Brown, S.B., Hankinson, S.E. (2015). Endogenous estrogens and the risk of breast, endometrial, and ovarian cancers. Steroids, 99(Pt A), 8-10.

19. Buchmann, S., Zahm, A., Kolling-Speer, I., Speer, K. (2011). Lipids in coffee brews - impact of grind size, water temperature, and coffee/water ratio on cafestol and the carboxylic acid-5-hydroxytryptamides. In: 23rd International Conference on Coffee Science, Bali, Indonesia, 3-8.10.2010, vol. 1. Curran Associates, Inc., Red Hook, NY, USA. pp. 84-92.

20. Cárdenas, C., Quesada, A.R., Medina, M.A. (2011). Anti-angiogenic and anti-inflammatory properties of kahweol, a coffee diterpene. PLoS ONE, 6(8), art. no. e23407.

21. Cárdenas, C., Quesada, A.R., Medina, M.Á. (2014). Insights on the antitumor effects of kahweol on human breast cancer: decreased survival and increased production of reactive oxygen species and cytotoxicity. Biochemical \& Biophysical Research Communications, 447(3), 452-458.

22. Catalano, D., Trovato, G.M., Spadaro, D., Martines, G.F., Garufi, G., Tonzuso, A., Grasso, D., Sciacchitano, S.G. (2008). Insulin resistance in postmenopausal women: concurrent effects of hormone replacement therapy and coffee. Climacteric, 11(5), 373-382.

23. Centers for Disease Control and Prevention. Leading causes of death in females. CDC, 2013. Available online: [https://www. cdc.gov/women/lcod/index.htm] (accessed on 6 December 2019).

24. DePaula, J., Farah, A. (2019). Caffeine consumption through coffee: content in the beverage, metabolism, health benefits and risks. Beverages, 2019, 5(2), art. no. 37.

25. Danaei, G., Vander Hoorn, S., Lopez, A.D., Murray, C.J., Ezzati, M. (2005). Comparative Risk Assessment collaborating group (Cancers). Causes of cancer in the world: comparative risk assessment of nine behavioural and environmental risk factors. Lancet, 366(9499), 1784-1793.

26. Diep, C.H., Daniel, A.R., Mauro, L.J., Knutson, T.P., Lange, C.A. (2015). Progesterone action in breast, uterine, and ovarian cancers. Journal of Molecular Endocrinology, 54(2), R31-R53.

27. Ding, M., Bhupathiraju, S.N., Chen, M., van Dam, R.M., Hu, F.B. (2014). Caffeinated and decaffeinated coffee consumption and risk of type 2 diabetes: a systematic review and a dose-response meta-analysis. Diabetes Care, 37(2), 569-586.

28. Doll, A., Abal, M., Rigau, M., Monge, M., Gonzalez, M., Demajo, S., Colás, E., Llauradó, M., Alazzouzi, H., Planagumá, J., Lohmann, M.A., Garcia, J., Castellvi, S., Ramon y Cajal, J., Gil-Moreno, A., Xercavins, J., Alameda, F., Reventós, J. (2008). Novel molecular profiles of endometrial cancer-new light through old windows. Journal of Steroid Biochemistry \& Molecular Biology, 108(3-5), 221-229.

29. EFSA. (2011). Results on acrylamide levels in food from monitoring years 2007-2009 and exposure assessment. EFSA Journal, 9(4), 2133. 
30. EFSA Panel on Contaminants in the Food Chain (CONTAM). (2015). Scientific opinion on acrylamide in food. EFSA Journal, 13(6), 4104.

31. Endogenous Hormones and Breast Cancer Collaborative Group, Key, T.J., Appleby, P.N., Reeves, G.K., Travis, R.C., Alberg, A.J., Barricarte, A., Berrino, F., Krogh, V., Sieri, S., Brinton, L.A., Dorgan, J.F., Dossus, L., Dowsett, M., Eliassen, A.H., Fortner, R.T., Hankinson, S.E., Helzlsouer, K.J., Hoffman-Bolton, J., Comstock, G.W., Kaaks, R., Kahle, L.L., Muti, P., Overvad, K., Peeters, P.H., Riboli, E., Rinaldi, S., Rollison, D.E., Stanczyk, F.Z., Trichopoulos, D., Tworoger, S.S., Vineis, P. (2013). Sex hormones and risk of breast cancer in premenopausal women: a collaborative reanalysis of individual participant data from seven prospective studies. Lancet Oncology, 14(10), 1009-1019.

32. European Commission. The state of women's health in the European Community. Available online: [https://ec.europa.eu/ health/state/publications/1996_state_women_pl] (accessed on 6 December 2019).

33. Fagherazzi, G., Touillaud, M.S., Boutron-Ruault, M.C., Clavel-Chapelon, F., Romieu, I. (2011). No association between coffee, tea or caffeine consumption and breast cancer risk in a prospective cohort study. Public Health \& Nutrition, 14(7), 1315-1320.

34. Ferlay, J., Soerjomataram, I., Dikshit, R., Eser, S., Mathers, C., Rebelo, M., Parkin, D.M., Forman, D., Bray, F. (2015). Cancer incidence and mortality worldwide: sources, methods and major patterns in GLOBOCAN 2012. International Journal of Cancer, 136(5), E359-E386.

35. Folkerd, E., Dowsett, M. (2013). Sex hormones and breast cancer risk and prognosis. Breast, 22 (Suppl 2), S38-S43.

36. Ford, D., Easton, D.F., Stratton, M., Narod, S., Goldgar, D., Devilee, P., Bishop, D.T., Weber, B., Lenoir, G., Chang-Claude, J., Sobol, H., Teare, M.D., Struewing, J., Arason, A., Scherneck, S., Peto, J., Rebbeck, T.R., Tonin, P., Neuhausen, S., Barkardottir, R., Eyfjord, J., Lynch, H., Ponder, B.A., Gayther, S.A., Zelada-Hedman, M. and The Breast Cancer Linkage Consortium. (1998). Genetic heterogeneity and penetrance analysis of the BRCA1 and BRCA2 genes in breast cancer families. American Journal of Human Genetics, 62 (3), 676-689.

37. Freisling, H., Moskal, A., Ferrari, P., Nicolas, G., Knaze, V., Clavel-Chapelon, F., Boutron-Ruault, M.C., Nailler, L., Teucher, B., Grote, V.A., Boeing, H., Clemens, M., Tjønneland, A., Olsen, A., Overvad, K., Quirós, J.R., Duell, E.J., Sánchez, M.J., Amiano, P., Chirlaque, M.D., Barricarte, A., Khaw, K.T., Wareham, N.J., Crowe, F.L., Gallo, V., Oikonomou, E., Naska, A., Trichopoulou, A., Palli, D., Agnoli, C., Tumino, R., Polidoro, S., Mattiello, A., Bueno-de-Mesquita, H.B., Ocké, M.C., Peeters, P.H., Wirfält, E., Ericson, U., Bergdahl, I.A., Johansson, I., Hjartåker, A., Engeset, D., Skeie, G., Riboli, E., Slimani, N. (2013). Dietary acrylamide intake of adults in the European Prospective Investigation into Cancer and Nutrition differs greatly according to geographical region. European Journal of Nutrition, 52 (4), 1369-1380.

38. Friberg, E., Orsini, N., Mantzoros, C.S., Wolk, A. (2009). Coffee drinking and risk of endometrial cancer - a population-based cohort study. International Journal of Cancer, 125(10), 2413-2417.

39. Gapstur, S.M., Anderson, R.L., Campbell, P.T., Jacobs, E.J., Hartman, T.J., Hildebrand, J.S., Wang, Y., McCullough, M.L. (2017). Associations of coffee drinking and cancer mortality in the Cancer Prevention Study-II. Cancer Epidemiology, Biomarkers \& Prevention, 26(10), 1477-1486.
40. Gavrilyuk, O, Braaten, T, Skeie, G, Weiderpass, E, Dumeaux, V, Lund, E. (2014). High coffee consumption and different brewing methods in relation to postmenopausal endometrial cancer risk in the Norwegian women and cancer study: a population-based prospective study. BMC Womens Health, 14(1), art. no. 48.

41. Gierach, G.L., Freedman, N.D., Andaya, A., Hollenbeck, A.R., Park, Y., Schatzkin, A., Brinton, L.A. (2012). Coffee intake and breast cancer risk in the NIH-AARP diet and health study cohort. International Journal of Cancer, 131 (2), 452-460.

42. Giri, A., Sturgeon, S.R., Luisi, N., Bertone-Johnson, E., Balasubramanian, R., Reeves, K.W. (2011). Caffeinated coffee, decaffeinated coffee and endometrial cancer risk: a prospective cohort study among US postmenopausal women. Nutrients, 3(11), 937-950.

43. Gorska-Ponikowska, M., Kuban-Jankowska, A., Daca, A., Nussberger, S. (2017). 2-methoxyestradiol reverses the pro-carcinogenic effect of 1-lactate in osteosarcoma 143B cells. Cancer Genomics \& Proteomics, 14(6), 483-493.

44. Gosvig, C.F., Kjaer, S.K., Blaakær, J., Høgdall, E., Høgdall, C., Jensen, A. (2015). Coffee, tea, and caffeine consumption and risk of epithelial ovarian cancer and borderline ovarian tumors: results from a Danish case-control study. Acta Oncologica, 54(8), 1144-1151.

45. Gross, G., Jaccaud, E., Huggett, A.C. (1997). Analysis of the content of the diterpenes cafestol and kahweol in coffee brews. Food Chemistry \& Toxicology, 35(6), 547-554.

46. Grosso, G., Micek, A., Godos, J., Sciacca, S., Pajak, A., Martínez-González, M.A., Giovannucci, E.L., Galvano, F. (2016). Coffee consumption and risk of all-cause, cardiovascular, and cancer mortality in smokers and non-smokers: a dose-response metaanalysis. European Journal of Epidemiology, 31(12), 1191-1205

47. Grosso, G., Godos, J., Galvano, F., Giovannucci, E.L. (2017a). Coffee, caffeine, and health outcomes: an umbrella review. Annual Review of Nutrition, 37(1), 131-156.

48. Grosso, G., Stepaniak, U., Micek, A., Stefler, D., Bobak, M., Pajak, A. (2017b). Coffee consumption and mortality in three Eastern European countries: results from the HAPIEE (Health, Alcohol and Psychosocial factors In Eastern Europe) study. Public Health \& Nutrition, 20(1), 82-91.

49. Gunter, M.J., Murphy, N., Cross, A.J., Dossus, L., Dartois, L., Fagherazzi, G., Kaaks, R., Kühn, T., Boeing, H., Aleksandrova, K., Tjønneland, A., Olsen, A., Overvad, K., Larsen, S.C., Redondo Cornejo, M.L., Agudo, A., Sánchez Pérez, M.J., Altzibar, J.M., Navarro, C., Ardanaz, E., Khaw, K.T., Butterworth, A., Bradbury, K.E., Trichopoulou, A., Lagiou, P., Trichopoulos, D., Palli, D., Grioni, S., Vineis, P., Panico, S., Tumino, R., Bueno-de-Mesquita, B., Siersema, P., Leenders, M., Beulens, J.W.J., Uiterwaal, C.U., Wallström, P., Nilsson, L.M., Landberg, R., Weiderpass, E., Skeie, G., Braaten, T., Brennan, P., Licaj, I., Muller, D.C., Sinha, R., Wareham, N., Riboli, E. (2017). Coffee drinking and mortality in 10 European countries: A multinational cohort study. Annals of Internal Medicine, 167(4), 236-247.

50. Hashibe, M., Galeone, C., Buys, S.S., Gren, L., Boffetta, P., Zhang, Z.F., La Vecchia, C. (2015). Coffee, tea, caffeine intake, and the risk of cancer in the PLCO cohort. British Journal of Cancer, 113(5), 809-816.

51. He, Z., Ma, W.Y., Hashimoto, T., Bode, A.M., Yang, C.S., Dong, Z. (2003). Induction of apoptosis by caffeine is mediated by the p53, Bax, and caspase 3 pathways. Cancer Research, 63(15), 4396-4401. 
52. Hernandez, A.V., Pasupuleti, V., Benites-Zapata, V.A., Thota, P., Deshpande, A., Perez-Lopez, F.R. (2015). Insulin resistance and endometrial cancer risk: A systematic review and meta-analysis. European Journal of Cancer, 51 (18), 2747-2758.

53. Hogervorst, J.G., Schouten, L.J., Konings, E.J., Goldbohm, R.A., van den Brandt, P.A. (2007). A prospective study of dietary acrylamide intake and the risk of endometrial, ovarian, and breast cancer. Cancer Epidemiology, Biomarkers \& Prevention, 16(11), 2304-2313.

54. Huber, W.W., Parzefall, W. (2005). Modification of N-acetyltransferases and glutathione S-transferases by coffee components: possible relevance for cancer risk. Methods in Enzymology, 401, 307-341.

55. Huber, W.W., Scharf, G., Nagel, G., Prustomersky, S., Schulte-Hermann, R., Kaina, B. (2003). Coffee and its chemopreventive components kahweol and cafestol increase the activity of O6-methylguanine-DNA methyltransferase in rat liver - comparison with phase II xenobiotic metabolism. Mutation Research, 522(1-2), 57-68.

56. Ito, K., Nakazato, T., Miyakawa, Y., Yamato, K., Ikeda, Y., Kizaki, M. (2003). Caffeine induces G2/M arrest and apoptosis via a novel p53-dependent pathway in NB4 promyelocytic leukemia cells. Journal of Cell Physiology, 196(2), 276-283.

57. Je, Y, Giovannucci, E. (2012). Coffee consumption and risk of endometrial cancer: findings from a large up-to-date metaanalysis. International Journal of Cancer, 131 (7), 1700-1710.

58. Je, Y., Hankinson, S.E., Tworoger, S.S., De Vivo, I., Giovannucci, E. (2011). A prospective cohort study of coffee consumption and risk of endometrial cancer over a 26-year follow-up. Cancer Epidemiology, Biomarkers \& Prevention, 20(12), 2487-2495.

59. Jeon, J.S., Kim, H.T, Jeong, I.H., Hong, S.R., Oh, M.S., Yoon, M.H., Shim, J.H., Jeong, J.H., Abd El-Aty, A.M. (2019). Contents of chlorogenic acids and caffeine in various coffee-related products. Journal of Advanced Research, 17, 85-94.

60. Jiang, W., Wu, Y., Jiang, X. (2013). Coffee and caffeine intake and breast cancer risk: an updated dose-response meta-analysis of 37 published studies. Gynecological Oncology, 129(3), 620-629.

61. Korir, M.W., Wachira, F.N., Wanyoko, J.K., Ngure, R.M., Khalid, R. (2014). The fortification of tea with sweeteners and milk and its effect on in vitro antioxidant potential of tea product and glutathione levels in an animal model. Food Chemistry, 145, 145-153.

62. Kotemori, A., Ishihara, J., Zha, L., Liu, R., Sawada, N., Iwasaki, M., Sobue, T., Tsugane, S., JPHC Study Group. (2018). Dietary acrylamide intake and risk of breast cancer: The Japan Public Health Center-based Prospective Study. Cancer Science, 109(3), 843-853.

63. Kotsopoulos, J., Eliassen, A.H., Missmer, S.A., Hankinson, S.E., Tworoger, S.S. (2009). Relationship between caffeine intake and plasma sex hormone concentrations in premenopausal and postmenopausal women. Cancer, 115(12), 2765-2774.

64. Kotsopoulos, J., Ghadirian, P., El-Sohemy, A., Lynch, H.T., Snyder, C., Daly, M., Domchek, S., Randall, S., Karlan, B., Zhang, P., Zhang, S, Sun P., Narod, S.A. (2007). The CYP1A2 genotype modifies the association between coffee consumption and breast cancer risk among BRCA1 mutation carriers. Cancer Epidemiology, Biomarkers \& Prevention, 16(5), 912-916.

65. Lafranconi, A., Micek, A., De Paoli, P., Bimonte, S., Rossi, P., Quagliariello, V., Berretta, M. (2018). Coffee intake decreases risk of postmenopausal breast cancer: a dose-response meta-analysis on prospective cohort studies. Nutrients, 10(2), art. no. e112.

66. Lafranconi, A., Micek, A., Galvano, F., Rossetti, S., Del Pup, L., Berretta, M., Facchini, G. (2017). Coffee decreases the risk of endometrial cancer: a dose-response meta-analysis of prospective cohort studies. Nutrients, 9(11), art no. e1223.

67. Lang, R., Yagar, E.F., Eggers, R., Hofmann, T. (2008). Quantitative investigation of trigonelline, nicotinic acid, and nicotinamide in foods, urine, and plasma by means of LC-MS/MS and stable isotope dilution analysis. Journal of Agricultural and Food Chemistry, 56(23), 11114-11121.

68. Larsson, S.C., Akesson, A., Wolk, A. (2009). Long-term dietary acrylamide intake and risk of epithelial ovarian cancer in a prospective cohort of Swedish women. Cancer Epidemiology, Biomarkers \& Prevention, 18(3), 994-997.

69. Lee, P.M.Y, Chan, W.C., Kwok, C.C., Wu, C., Law, S.H., Tsang, K.H., Yu, W.C., Yeung, Y.C., Chang, L.D.J., Wong, C.K.M., Wang, F., Tse, L.A. (2019). Associations between coffee products and breast cancer risk: a case-control study in Hong Kong Chinese women. Scientific Reports, 2019, 9(1), art. no. 12684.

70. Leung, A.C., Cook, L.S., Swenerton, K., Gilks, B., Gallagher, R.P., Magliocco, A., Steed, H., Köbel, M., Nation, J., Brooks-Wilson, A., Le N.D. (2016). Tea, coffee, and caffeinated beverage consumption and risk of epithelial ovarian cancers. Cancer Epidemiology, 45, 119-125.

71. Li, J., Seibold, P., Chang-Claude, J., Flesch-Janys, D., Liu, J., Czene, K., Humphreys, K., Hall, P. (2011). Coffee consumption modifies risk of estrogen-receptor negative breast cancer. Breast Cancer Research, 13(3), R49.

72. Liu, Q.P., Wu, Y.F., Cheng, H.Y., Xia, T., Ding, H., Wang, H., Wang, Z.M., Xu, Y. (2016). Habitual coffee consumption and risk of cognitive decline/dementia: A systematic review and meta-analysis of prospective cohort studies. Nutrition, 32(6), 628-636.

73. Loftfield, E., Shiels, M.S., Graubard, B.I., Katki, H.A., Chaturvedi, A.K., Trabert, B., Pinto, L.A., Kemp, T.J., Shebl, F.M., Mayne, S.T., Wentzensen, N., Purdue, M.P., Hildesheim, A., Sinha, R., Freedman, N.D. (2015). Associations of coffee drinking with systemic immune and inflammatory markers. Cancer Epidemiology, Biomarkers \& Prevention, 24(7), 1052-1060.

74. Ludwig, I.A., Mena, P., Calani, L., Cid, C., Del Rio, D., Lean, M.E., Crozier, A. (2014). Variations in caffeine and chlorogenic acid contents of coffees: what are we drinking? Food \& Function, 5(8), 1718-1726.

75. Lukic, M., Guha, N., Licaj, I., van den Brandt, P.A., Stayner, L.T., Tavani, A., Weiderpass, E. (2018). Coffee drinking and the risk of endometrial cancer: an updated meta-analysis of observational studies. Nutrition \& Cancer, 70(4), 513-528.

76. Lukic, M., Licaj, I., Lund, E., Skeie, G., Weiderpass, E., Braaten, T. (2016). Coffee consumption and the risk of cancer in the Norwegian women and cancer (NOWAC) Study. European Journal of Epidemiology, 31 (9), 905-916.

77. Madeira, M.H., Boia, R., Ambrósio, A.F., Santiago, A.R. (2017). Having a coffee break: the impact of caffeine consumption on microglia-mediated inflammation in neurodegenerative diseases. Mediators of Inflammation, 2017, art. no. 4761081.

78. Mazur, W.M., Wähälä, K., Rasku, S., Salakka, A., Hase, T., Adlercreutz, H. (1998). Lignan and isoflavonoid concentrations in tea and coffee. British Journal of Nutrition, 79(1), 37-45. 
79. Mellbye, F.B., Jeppesen, P.B., Hermansen, K., Gregersen, S. (2015). Cafestol, a bioactive substance in coffee, stimulates insulin secretion and increases glucose uptake in muscle cells: Studies in vitro. Journal of Natural Products, 78(10), 2447-2451.

80. Mensink, R.P., Lebbink, W.J., Lobbezoo, I.E., Weusten-Van der Wouw, M.P., Zock, P.L., Katan, M.B. (1995). Diterpene composition of oils from Arabica and Robusta coffee beans and their effects on serum lipids in man. Journal of Internal Medicine, 237(6), 543-550.

81. Merritt, M.A., Tzoulaki, I., Tworoger, S.S., De Vivo, I., Hankinson, S.E., Fernandes, J., Tsilidis, K.K., Weiderpass, E., Tjønneland, A., Petersen, K.E., Dahm, CC., Overvad, K., Dossus, L., Boutron-Ruault, M.C., Fagherazzi, G., Fortner, R.T., Kaaks, R., Aleksandrova, K., Boeing, H., Trichopoulou, A., Bamia, C., Trichopoulos, D., Palli, D., Grioni, S., Tumino, R., Sacerdote, C., Mattiello, A., Bueno-de-Mesquita, H.B., Onland-Moret, N.C., Peeters, P.H., Gram, I.T., Skeie, G., Quirós, J.R., Duell, E.J., Sánchez, M.J., Salmerón, D., Barricarte, A., Chamosa, S., Ericson, U., Sonestedt, E., Nilsson, L.M., Idahl, A., Khaw, K.T., Wareham, N., Travis, R.C., Rinaldi, S., Romieu, I., Patel, C.J., Riboli, E., Gunter, M.J. (2015). Investigation of dietary factors and endometrial cancer risk using a nutrient-wide association study approach in the EPIC and Nurses' Health Study (NHS) and NHSII. Cancer Epidemiology, Biomarkers \& Prevention, 24(2), 466-471.

82. Michels, K.A., Brinton, L.A., Wentzensen, N., Pan, K., Chen, C., Anderson, G.L., Pfeiffer, R.M., Xu, X., Rohan, T.E., Trabert, B. (2019). Postmenopausal androgen metabolism and endometrial cancer risk in the Women's Health Initiative Observational Study. JNCI Cancer Spectrum, 3(3), art. no. pkz029.

83. Mojska, H., Gielecińska, I., Szponar, L., Ołtarzewski, M. (2010). Estimation of the dietary acrylamide exposure of the Polish population. Food and Chemical Toxicology, 48(8-9), 2090-2096.

84. Mojska, H., Gielecińska, I. (2013). Studies of acrylamide level in coffee and coffee substitutes: influence of raw material and manufacturing conditions. Roczniki Państwowego Zaktadu Higieny, 64(3), 173-181.

85. Nagata, C., Kabuto, M., Shimizu, H. (1998). Association of coffee, green tea, and caffeine intakes with serum concentrations of estradiol and sex hormone-binding globulin in premenopausal Japanese women. Nutrition \& Cancer, 30(1), 21-24.

86. Nikitina, D., Chen, Z., Vallis, K., Poll, A., Ainsworth, P., Narod, S.A., Kotsopoulos, J. (2015). Relationship between caffeine and levels of DNA repair and oxidative stress in women with and without a BRCA1 mutation. Journal of Nutrigenetics \& $\mathrm{Nu}$ trigenomics, 8(4-6), 174-184.

87. Nilsson, L.M., Johansson, I., Lenner, P., Lindahl, B., Van Guelpen, B. (2010). Consumption of filtered and boiled coffee and the risk of incident cancer: a prospective cohort study. Cancer Causes Control, 21(10), 1533-1544.

88. Nkondjock, A., Ghadirian, P., Kotsopoulos, J., Lubinski, J., Lynch, H., Kim-Sing, C., Horsman, D., Rosen, B., Isaacs, C., Weber, B., Foulkes, W., Ainsworth, P., Tung, N., Eisen, A., Friedman, E., Eng, C., Sun, P., Narod, S.A. (2006). Coffee consumption and breast cancer risk among BRCA1 and BRCA2 mutation carriers. International Journal of Cancer, 118(1), 103-107.

89. Obón-Santacana, M., Lujan-Barroso, L., Travis, R.C., Freisling, H., Ferrari, P., Severi, G., Baglietto, L., Boutron-Ruault, M.C., Fortner, R.T., Ose, J., Boeing, H., Menéndez, V., Sánchez-Can- talejo, E., Chamosa, S., Castaño, J.M., Ardanaz, E., Khaw, K.T., Wareham, N., Merritt, M.A., Gunter, M.J., Trichopoulou, A., Papatesta, E.M., Klinaki, E., Saieva, C., Tagliabue, G., Tumino, R., Sacerdote, C., Mattiello, A., Bueno-de-Mesquita, H.B., Peeters, P.H., Onland-Moret, N.C., Idahl, A., Lundin, E., Weiderpass, E., Vesper, H.W., Riboli, E., Duell, E.J. (2016). Acrylamide and glycidamide hemoglobin adducts and epithelial ovarian cancer: a nested case-control study in nonsmoking postmenopausal women from the EPIC cohort. Cancer Epidemiology, Biomarkers \& Prevention, 25(1), 127-134.

90. Oh, J.K., Sandin, S., Ström, P., Löf, M., Adami, H.O., Weiderpass, E. (2015). Prospective study of breast cancer in relation to coffee, tea and caffeine in Sweden. International Journal of Cancer, 137(8), 1979-1989.

91. Ong, J.S., Hwang, L.D., Cuellar-Partida, G., Martin, N.G., Chenevix-Trench, G., Quinn, M.C.J., Cornelis, M.C., Gharahkhani, P., Webb, P.M., MacGregor, S. (2018). Assessment of moderate coffee consumption and risk of epithelial ovarian cancer: a Mendelian randomization study. International Journal of Epidemiology, 47(2), 450-459.

92. Park, S.Y., Freedman, N.D., Haiman, C.A., Le Marchand, L., Wilkens, L.R., Setiawan, V.W. (2018). Prospective study of coffee consumption and cancer incidence in non-white populations. Cancer Epidemiology, Biomarkers \& Prevention, 27(8), 928-935.

93. Pelucchi, C., Bosetti, C., Galeone, C., La Vecchia, C. (2015). Dietary acrylamide and cancer risk: an updated meta-analysis. International Journal of Cancer, 136(12), 2912-2922.

94. Poole, R., Kennedy, O.J., Roderick, P., Fallowfield, J.A., Hayes, P.C., Parkes, J. (2017). Coffee consumption and health: umbrella review of meta-analyses of multiple health outcomes. BMJ, 359, art. no. j5024.

95. Qi, H., Li, S. (2014). Dose-response meta-analysis on coffee, tea and caffeine consumption with risk of Parkinson's disease. Geriatrics \& Gerontology International, 14(2), 430-439.

96. Raglan, O., Kalliala, I., Markozannes, G., Cividini, S., Gunter, M.J., Nautiyal, J., Gabra, H., Paraskevaidis, E., Martin-Hirsch, P., Tsilidis, K.K., Kyrgiou, M. (2019). Risk factors for endometrial cancer: An umbrella review of the literature. International Journal of Cancer, 145(7), 1719-1730.

97. Rietjens, I.M.C.M., Louisse, J., Beekmann, K. (2017). The potential health effects of dietary phytoestrogens. British Journal Pharmacology, 174(11), 1263-1280.

98. Rodríguez-Artalejo, F., López-García, E. (2018). Coffee consumption and cardiovascular disease: a condensed review of epidemiological evidence and mechanisms. Journal of Agricultural and Food Chemistry, 66(21), 5257-5263.

99. Rosendahl, A.H., Perks, C.M., Zeng, L., Markkula, A., Simonsson, M., Rose, C., Ingvar, C., Holly, J.M., Jernström, H. (2015). Caffeine and caffeic acid inhibit growth and modify estrogen receptor and insulin-like growth factor I receptor levels in human breast cancer. Clinical Cancer Research, 21 (8), 1877-1887.

100. Rossi, M., Tavani, A., Ciociola, V., Ferraroni, M., Parpinel, M., Serafini, M., Bellocco, R., Zucchetto, A., Montella, M., Serraino, D., Lagiou, P., La Vecchia, C. (2016). Dietary total antioxidant capacity in relation to endometrial cancer risk: a casecontrol study in Italy. Cancer Causes \& Control, 27(3), 425-431.

101. Saiki, S., Sasazawa, Y., Imamichi, Y., Kawajiri, S., Fujimaki, T., Tanida, I., Kobayashi, H., Sato, F., Sato, S., Ishikawa, K., Imoto, M., Hattori, N. (2011). Caffeine induces apoptosis 
by enhancement of autophagy via PI3K/Akt/mTOR/p70S6K inhibition. Autophagy, 7(2), 176-187.

102. Sapozhnikova, Y. (2014). Development of liquid chromatography-tandem mass spectrometry method for analysis of polyphenolic compounds in liquid samples of grape juice, green tea and coffee. Food Chemistry, 150, 87-93.

103. Samoggia, A., Riedel, B. (2019). Consumers' perceptions of coffee health benefits and motives for coffee consumption and purchasing. Nutrients, 11 (3), art. no. e653.

104. Shafiei, F., Salari-Moghaddam, A., Milajerdi, A., Larijani, B., Esmaillzadeh, A. (2019). Coffee and caffeine intake and risk of ovarian cancer: a systematic review and meta-analysis. International Journal of Gynecology \& Cancer, 29(3), 579-584.

105. Sirota, R., Gibson, D., Kohen, R. (2015). The role of the catecholic and the electrophilic moieties of caffeic acid in Nrf2/ Keap1 pathway activation in ovarian carcinoma cell lines. Redox Biology, 4, 48-59.

106. Sisti, J.S., Hankinson, S.E., Caporaso, N.E., Gu, F., Tamimi, R.M., Rosner, B., Xu, X., Ziegler, R., Eliassen, A.H. (2015). Caffeine, coffee, and tea intake and urinary estrogens and estrogen metabolites in premenopausal women. Cancer Epidemiology, Biomarkers \& Prevention, 24(8), 1174-1183.

107. Tai, J., Cheung, S., Chan, E., Hasman, D. (2010). Antiproliferation effect of commercially brewed coffees on human ovarian cancer cells in vitro. Nutrition \& Cancer, 62 (8), 1044-1057.

108. Teixeira, J., Gaspar, A., Garrido, E.M., Garrido, J., Borges, F. (2013). Hydroxycinnamic acid antioxidants: an electrochemical overview. BioMed Research International, 2013, art. no. 251754.

109. Tetens, I., Turrini, A., Tapanainen, H., Christensen, T., Lampe, J.W., Fagt, S., Håkansson, N., Lundquist, A., Hallund, J., Valsta, L.M. (2013). The Phytohealth WP1 working group. Dietary intake and main sources of plant lignans in five European countries. Food \& Nutrition Research, 57(1), art. no. 19805.

110. Uccella, S., Mariani, A., Wang, A.H., Vierkant, R.A., Cliby, W.A., Robien, K., Anderson, K.E., Cerhan, J.R. (2013). Intake of coffee, caffeine and other methylxanthines and risk of Type I vs Type II endometrial cancer. British Journal of Cancer, 109(7), 1908-1913.

111. Vinholes, J., Silva, B.M., Silva, L.R. (2015). Hydroxycinnamic acids (HCAS): Structure, biological properties and health effects. In Leon V. Berhardt (Ed)., Advances in Medicine and Biology, Nova Science Publishers, Hauppauge (NY), USA. pp. 1-33.

112. Weiderpass, E., Sandin, S., Lof, M., Oh, J.K., Inoue, M., Shimazu, T., Tsugane, S., Adami, H.O. (2014). Endometrial cancer in relation to coffee, tea, and caffeine consumption: a prospective cohort study among middle-aged women in Sweden. Nutrition \& Cancer, 66(7), 1132-1143.

113. WHO, World Health Organization. International Agency for Research on Cancer. (2018). IARC monographs on the evaluation of carcinogenic risks to humans. Some industrial chemicals. IARC, Lyon, France, pp. 247-289.

114. Wierzejska, R. (2016). Coffee consumption and cardiovascular diseases - has the time come to change dietary advice? A mini review. Polish Journal of Food and Nutrition Sciences, 66(1), 5-10.

115. Wilson, K.M., Mucci, L.A., Cho, E., Hunter, D.J., Chen, W.Y., Willett, W.C. (2009). Dietary acrylamide intake and risk of premenopausal breast cancer. American Journal of Epidemiology, 169(8), 954-961.
116. Wilson, K.M., Mucci, L.A., Rosner, B.A., Willett, W.C. (2010). A prospective study on dietary acrylamide intake and the risk for breast, endometrial, and ovarian cancers. Cancer Epidemiology, Biomarkers \& Prevention, 19(10), 2503-2515.

117. Witkowska, A.M., Waśkiewicz, A., Zujko, M.E., Szcześniewska, D., Stepaniak, U., Pająk, A., Drygas, W. (2018). Are total and individual dietary lignans related to cardiovascular disease and its risk factors in postmenopausal women? A nationwide study. Nutrients, 10(7), art no. e865.

118. Witkowska, A.M., Zujko, M.E., Waśkiewicz, A., Terlikowska, K.M., Piotrowski, W. (2015). Comparison of various databases for estimation of dietary polyphenol intake in the population of Polish adults. Nutrients, 7(11), 9299-9308.

119. Yaghjyan, L., Rich, S., Mao, L., Mai, V., Egan, KM. (2018). Interactions of coffee consumption and postmenopausal hormone use in relation to breast cancer risk in UK Biobank. Cancer Causes \& Control, 29(6), 519-525.

120. Yang, T.O., Crowe, F., Cairns, B.J., Reeves, G.K., Beral, V. (2015). Tea and coffee and risk of endometrial cancer: cohort study and meta-analysis. American Journal of Clinical Nutrition, $101(3), 570-578$.

121. Zamora-Ros, R., Knaze, V., Luján-Barroso, L., Kuhnle, G.G., Mulligan, A.A., Touillaud, M., Slimani, N., Romieu, I., Powell, N., Tumino, R., Peeters, P.H., de Magistris, M.S., Ricceri, F., Sonestedt, E., Drake, I., Hjartåker, A., Skie, G., Mouw, T., Wark, P.A., Romaguera, D., Bueno-de-Mesquita, H.B., Ros, M., Molina, E., Sieri, S., Quirós, J.R., Huerta, J.M., Tjønneland, A., Halkjær, J., Masala, G., Teucher, B., Kaas, R., Travis, R.C., Dilis, V., Benetou, V., Trichopoulou, A., Amiano, P., Ardanaz, E., Boeing, H., Förster, J., Clavel-Chapelon, F., Fagherazzi, G., Perquier, F., Johansson, G., Johansson, I., Cassidy, A., Overvad, K., González, C.A. (2012). Dietary intakes and food sources of phytoestrogens in the European Prospective Investigation into Cancer and Nutrition (EPIC) 24-hour dietary recall cohort. European Journal of Clinical Nutrition, 66(8), 932-941.

122. Zhang, C., Linforth, R., Fisk, I.D. (2012). Cafestol extraction yield from different coffee brew mechanisms. Food Research International, 49(1), 27-31.

123. Zhou, Q., Luo, M.L., Li, H., Li, M., Zhou, J.G. (2015). Coffee consumption and risk of endometrial cancer: a dose-response meta-analysis of prospective cohort studies. Scientific Reports, 5, art. no. 13410 .

124. Zhu, B.T., Wang, P., Nagai, M., Wen, Y., Bai, H.W. (2009). Inhibition of human catechol-O-methyltransferase (COMT)-mediated O-methylation of catechol estrogens by major polyphenolic components present in coffee. Journal of Steroid Biochemistry and Molecular Biology, 113(1-2), 65-74.

125. Zhu, Y., Kawaguchi, K., Kiyama, R. (2017). Differential and directional estrogenic signaling pathways induced by enterolignans and their precursors. PLOS ONE, 12(2), art. no. e0171390.

126. Ziegler, R.G., Fuhrman, B.J., Moore, S.C., Matthews, C.E. (2015). Epidemiologic studies of estrogen metabolism and breast cancer. Steroids, 99, 67-75.

Submitted: 11 December 2019. Revised: 14 February and 1 April 2020. Accepted: 2 April 2020. Published on-line: 25 May 2020. 